\title{
Measuring the Impact of File Sharing on the Movie Industry: An Empirical Analysis Using a Panel of Countries
}

\author{
Alejandro Zentner
}

The music industry has struggled during the past decade due to file sharing and movie business executives fear the same fate. This paper seeks to provide measurements of the effects of peer-to-peer file sharing on the movie industry. We use a long panel of data at the country level containing information on theatrical, video rental, and video retail movie commercial performances, as well as Internet and broadband penetration. We compare the impacts of increased high-speed online connectedness replacing slow-speed Internet connectedness before and after the introduction of the second-generation file sharing technology that has made movie file sharing feasible. This empirical strategy allows us to isolate the effects of file sharing from any other possible Internet impacts on the commercial performance of movies unrelated to file sharing. Our results indicate that the effect of peer-to-peer file sharing is negative and large on video sales, but we do not have confidence regarding the impacts of file sharing on either the theatrical commercial performance of movies or video rentals. 


\section{I-Introduction}

Second-generation file sharing technology along with increasing bandwidth speeds are pressing concerns for the movie industry. Record companies have suffered substantial losses due to file sharing and movie studios fear following the same path. Music sales have decayed substantially since the creation of file sharing technology a decade ago. Figure I shows that revenues for the music industry in the United States, including sales of both physical music (e.g., CDs) and digital music (e.g., iTunes), have decreased by $54 \%$ since 1999. ${ }^{1}$ Although the US movie industry did not show signs of having been affected by file sharing in the early file sharing years, the more recent business performance trends are negative. Figure I shows that the trend in US theatrical revenues changed in 2003 following several years of substantial growth. This coincides with the development of the BitTorrent network which uses a second-generation file sharing technology that has made swapping large movie files practical. The retail video markets (including sales of both DVDs and VHSs) grew rapidly until 2004 and have since decayed sharply. Video sales revenues decreased 27\% from 2004 to 2008. Video rental revenues have decayed monotonically since 2000 .

\section{Figure I}

\section{Revenues in the United States: Movie and Music Industries (measured in constant 2008 million US dollars)}

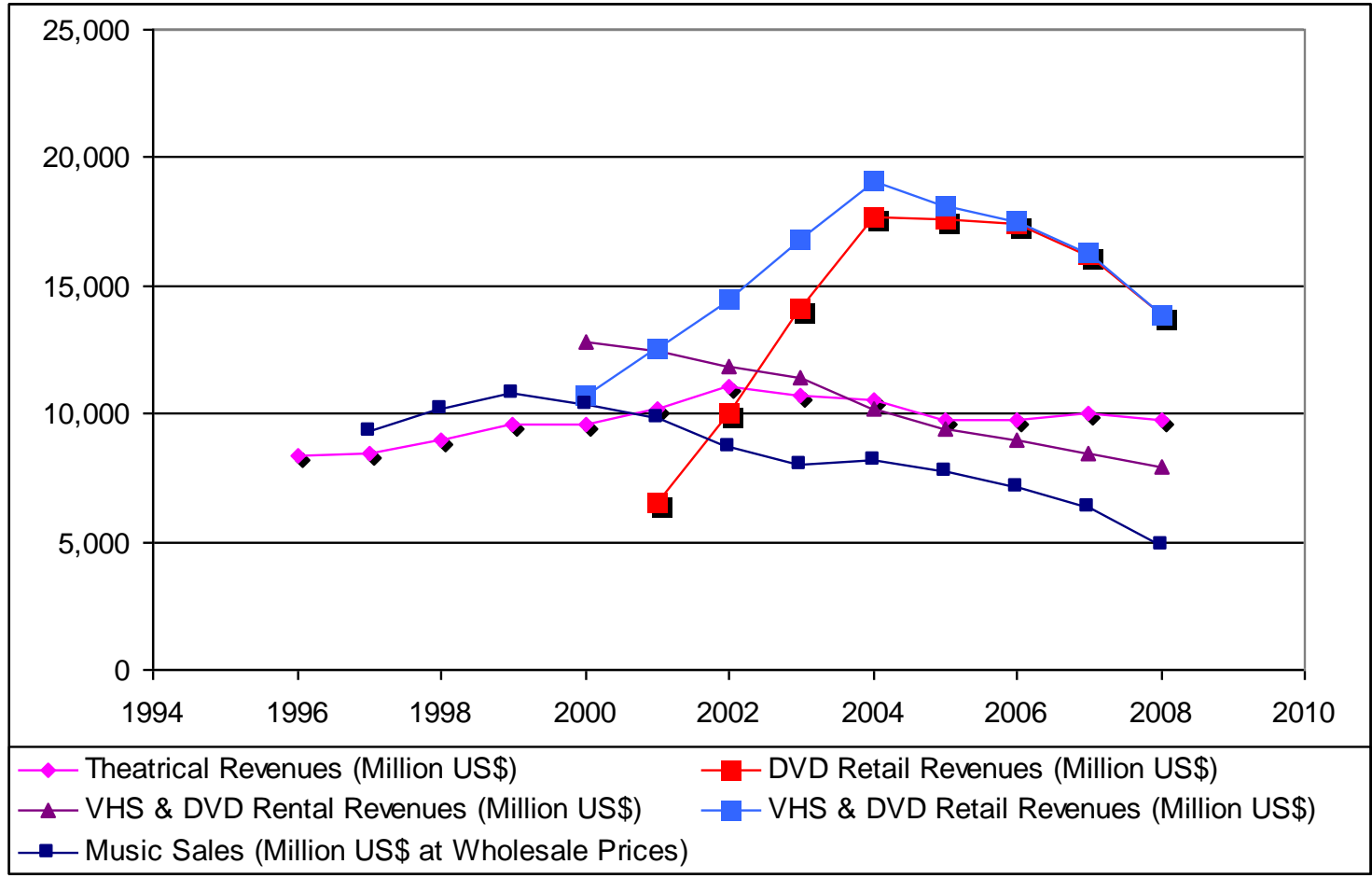

\footnotetext{
${ }^{1}$ Sales of music are from the International Federation of Phonographic Industry (IFPI) measured at wholesale prices. The statistics for the movie industry are from the European Audiovisual Observatory and the International Video Federation measured at retail prices. Sales of physical music (not including legal downloads) in the US have decreased by $64 \%$ since 1999.
} 
These decaying revenue trends and the recent sharp decay in video sales revenues in particular raise the question of whether or not the swapping of movies via peer-to-peer networks is hurting the movie industry. Improved file sharing technology and ubiquitous high-speed connections are a great concern of movie industry executives. Although the aggregate statistics for the movie industry are not as yet conclusive as is the case for sound recordings, the movie industry perceives these changes in revenue trends as an early warning sign. Are the recent downward trends in revenues harbingers of its future fate?

This paper seeks to measure the effect of file sharing on movie commercial performance using data at the country level. Our approach is to examine whether or not theatrical and video commercial movie performances have decayed more rapidly in countries experiencing faster increases in the adoption of file sharing technologies. In the absence of statistics on the amount of file sharing we use data on online connectedness for each country. Of course, the Internet may have an impact on the commercial performance of movies for reasons unrelated to file sharing (e.g., word of mouth promotion). Additionally, unobservable factors that affect movie commercial performances may happen to be correlated with the increase in Internet use. In this case, the impact of the Internet on movie commercial performances will not reflect the pure impact of file sharing on the movie industry because the increase in Internet penetration will absorb the effect of such unobservable confounding factors. In order to isolate the effect of file sharing from any other Internet effect, we use an empirical strategy exploiting the speed of the Internet connections and technological constraints that limited the amount of movie file sharing before the year 2003. A high-speed connection is required for downloading large movie files but may not be as essential for acquiring information about films or using the Internet as an entertainment medium. Using total Internet penetration and broadband Internet penetration in the regressions allows us to study how the commercial performance of movies changes when increasing broadband penetration, while holding fixed the level of Internet penetration. Comparing the effect of increased broadband connectedness when movie file sharing was not yet feasible (from a practical standpoint) with its effect after the creation of the torrent file sharing technology may allow the separation of the file sharing impact from other Internet effects unrelated to file sharing.

The introduction of BitTorrent in 2003 revolutionized movie file sharing. Although it was technically feasible to download movies using older file sharing architectures, the "torrent" technology made it practical because it substantially reduced the downloading time of large movie files. Downloading a movie file used to take several days before the introduction of the torrent technology and takes between one and a few hours employing the torrent technology. The BitTorrent protocol gained popularity quickly after its introduction, accounting for one third of all Internet traffic at the end of 2004. Concurrent with the increase in movie file sharing, the Motion Picture Association of America (MPAA) began suing individuals for illegally downloading movie files in November of 2004 (Wired 2005). ${ }^{2}$

\footnotetext{
${ }^{2}$ Comparatively, the Recording Industry Association of America (RIAA) began filing lawsuits against file sharing users who downloaded copyrighted music in September of 2003.
} 
Our findings, in short, indicate that the unauthorized downloading of movies decreases video sales by a substantial amount. We do not find conclusive results on whether or not file sharing decreases either the theatrical performance of movies or video rentals, because the size of these impacts vary widely in alternative model specifications.

The question of whether or not file sharing has reduced music sales has received substantial attention (see Rob and Waldfogel 2006 and Zentner 2009 for lists of references). On the other hand, the study of whether or not file sharing affects the movie industry has received scant attention. There are a few exceptions. ${ }^{3}$ Rob and Waldfogel (2007) use survey data for the years 2002 through 2005 on movie consumption by approximately 500 students in the US, finding that one pirated movie consumption reduces approximately one paid movie consumption. Although this paper finds that the rate of displacement is large, it also finds that the amount of displacement is small, which is explained by the low level of pirated consumption in their sample (only 5.2 percent of total movie consumption in their sample is unpaid). Bai and Waldfogel (2009) use two samples of Chinese consumers (a sample of college students and a sample of Internet users); documenting that nearly three quarters of movie consumption in their samples is unpaid (and mostly obtained via downloading) but finding that the displacement is small: each unpaid consumption displaces 0.14 paid consumptions in the sample of college students and the displacement is roughly zero in the Internet sample. Bounie, Bourreau, and Waelbroek (2006) use survey data on 620 French individuals collected in 2005, finding in their sample that file sharing has no impact on theatrical attendance but a large impact on both video rentals and sales. In this literature, our paper is most closely related to Smith and Telang (2008) and Danaher and Waldfogel (2012). Smith and Telang (2008) use data on DVD sales in American cities for the years 2000 through 2003, finding that increases in broadband penetration had a positive association with DVD sales. Danaher and Waldfogel (2012) also make use of the appearance of BitTorrent in 2003, examining whether after the appearance of BitTorrent release lags of movies in international markets decrease theatrical box-office revenues. They find that longer lags decrease theatrical attendance.

In this paper we use aggregate data for a panel of countries. Using aggregate data has an important advantage over the use of individual-level data for quantifying the effect of file sharing on digital goods in general, including movie sales. Individuals do not download digital files solely for their own consumption but may also make copies for their friends and family. In this manner, many individuals who do not personally download digital files are nevertheless able to view movies without purchasing them. The use of data at an aggregate locational level circumvents this problem by aiming to measure aggregate file sharing and paid consumption at the community level. ${ }^{4}$

The outline of the remainder of the paper is as follows. The next section presents relevant background on the movie industry and file sharing technology. Section III lays out the

\footnotetext{
${ }^{3}$ Waterman, Wook, and Rochet (2007) provide a detailed economic survey of the strategies the movie industry has used to deter copying.

${ }^{4}$ Rob and Waldfogel (2007) use individual-level data, but avoid this problem by asking individuals

whether or not they watched downloaded movies as opposed to whether or not they downloaded movies.
} 
empirical strategy. Section IV describes the data used in this study. Section V presents the estimation results. Section VI discusses some challenges to our identification strategy. The final section offers some conclusions.

\section{II- Industry and File Sharing Background: Music versus Movies}

The study of whether or not file sharing has an impact on the movie industry relates closely to the research studying the effect of file sharing on music sales. In this section we briefly point out some relevant differences between the movie and music industries. ${ }^{5}$

Movies are released sequentially in different forms, known as "windowing" in movie industry jargon. The release of a movie in theaters is usually followed by a sequence of releases in prerecorded DVD format, video downloads (e.g., streaming movies from Netflix), premium cable (e.g., pay-per-view), regular cable, and network television. The movie industry generates revenues from each of these outlets, and it is plausible that file sharing displaces revenues from each of these outlets with different intensities. We do not have data on cable and therefore focus our attention on theatrical releases and prerecorded movies (both sales and rentals). Although the rental and retail of video downloads (e.g., streaming movies from Netflix) have recently gained importance we show below that these forms of consumption were negligible during our study period.

Files available for downloading in file sharing networks may come from different sources. Sometimes peer-to-peer networks have movie files available for downloading even before the movie has been released in theaters. This has been more frequent overseas because movies have typically been released abroad with a lag. In fact, movie studios are now clustering the international theatrical releases of top movies as a way to prevent piracy. ${ }^{6}$ Copies of movies sent to movie critics have in some instances ended up on peer-to-peer networks before these movies are released in theaters. In other instances people involved in the post-production process may leak a copy to the Internet. One copy of the movie that ends up on the Internet suffices to meet the demand of all peer-to-peer users, due to the public good nature of digital files. After the theatrical release, digital copies are made by taping movies in theaters using a camcorder. The quality of these copies varies widely. A "cam" is a low-fidelity copy made using a regular camcorder. A "telesync" is also a copy made in the theater, but using a superior professional camcorder that is often set on a tripod in the projection booth with a connection hooked to the audio source. Low quality "cam" copies are usually available on peer-to-peer networks on the day of the theatrical debut, and better quality copies become available a few days later. On a few occasions digital copies have been made from stolen analog cinema reels.

\footnotetext{
${ }^{5}$ See Zentner (2005) and Zentner (2009) for a description of the music industry, a description of file sharing technology, a list of references, and other issues relevant for measuring the effect of file sharing on music sales.

${ }^{6}$ This strategy may be costly for movie studios for several reasons. For example, clustering international film releases prevents movie studios from using the performance of movies in the US when planning how many screens to assign to each movie. The clustering of international releases also prevents movie studios from re-using costly movie reels in different countries.
} 
Before the official DVD release it is common to find illegal copies made from legitimate advance DVD copies used for screening and marketing purposes. ${ }^{7}$ High-quality copies made from DVDs are always available online for download after DVDs have been officially released. The quality may sometimes be known before downloading from the comments of previous users.

There are several important considerations regarding how individuals consume movies compared to they way they consume music. First, significant repeated play of a movie is not typical (with the exception of children's movies), while repeated play and slow satiation are paramount characteristics of music consumption. This difference between movies and music may explain why the rental of music has been far less successful than the rental of videos. ${ }^{8}$ Second, consumers usually purchase music after listening to the songs, which makes sampling of the product more typical for the music industry than for the movie industry. Third, movies are a foreground activity that requires full attention. Music, on the other hand, allows individuals to multitask (e.g., surf the Internet or wash the dishes while they listen to music). Fourth, language is more important for movies than for music, although subtitles and dubbing do not seem to have deterred online movie swapping. Both subtitled and dubbed versions of movies in different languages are widely available for download from peer-to-peer networks.

File sharing technology for swapping music files was made popular in June of 1999 with the creation of Napster. Before Napster file sharing was an obscure activity and one in which very few individuals participated. Napster was shut down in February of 2001 for, "engaging in or enabling, facilitating or assisting others in the copying, downloading, uploading, transmission, or distribution of copyrighted musical work or sound recordings protected by copyright or state law without the express permission of the rights owners" (US District Court, 2000). Many peer-to-peer alternatives for sharing music over the Internet followed. However, the original peer-to-peer networks were not efficient for transferring large multi-gigabyte movie files since upload speeds tend to be slow compared to download speeds, and this slower upload speed was the constraint. Improvements in file sharing technology revolutionized movie file sharing in 2003. The new (torrent) technology allows the rapid sharing of large files by partitioning these files into several pieces. These files are then simultaneously transferred to many peers in a process in which the person downloading a file is also simultaneously providing partitions of this file for other peers to download. Downloads of a large file are performed by obtaining a small piece of the file from many computers, and in this way the torrent technology circumvents the generally slow upstream speed of broadband connections. ${ }^{9}$ The actual downloading time ranges from one to a few hours depending on the size of the file, the number of users downloading it (it is faster when more peers are downloading the file), and the speed of the connection.

\footnotetext{
${ }^{7}$ It is quite common to find pirate copies containing a legend revealing that they are made from "screeners."

${ }^{8}$ The rental of prerecorded music is not legal in the US, but is popular in Japan.

${ }^{9}$ See Paul Boutin (2004) for a 2004 perspective of how BitTorrent changed movie file sharing.
} 
Various factors would seem to indicate that movie file sharing displaces video consumption to a greater extent than theatrical attendance. First, except for cases where the original files are in some way leaked onto the Internet, the movie files on peer-to peer networks are usually of a better quality after the official release of the DVD than before this time. While the "telesync" files available on peer-to peer networks before the DVD release can be of good quality, the movie files obtained in peer-to-peer networks can be identical to the original DVDs files when these are released. Second, as a consumption experience watching a movie obtained online is a closer consumption experience to watching a DVD than to watching the movie at a theater (e.g., both are watched at home). Finally, both the files obtained online and purchased DVDs allow for repeated play of the movie, but consumers can only see a movie once per payment at the theater.

On the other hand, there are some important factors that suggest that file sharing may have caused a large decrease in theatrical attendance. First, the movie industry has always released the video version of movies with a lag following the release in theaters, based on the thought that videos would cannibalize theater performance if both releases were clustered. Although likely not identical to the original DVD, "telesync" copies may be of comparable quality to original DVDs for many individuals (the penetration of highdefinition DVD players was negligible during our period of analysis). ${ }^{10}$ Downloads may therefore cause a large displacement of theatrical attendance even when "telesync" copies are the only quality available on peer-to-peer networks. Second, although there is a tendency toward the clustering of movie releases in international markets, movies were typically released first in the US during our period of analysis. Some international consumers may have watched movies obtained from peer-to-peer networks before these were released in theaters in their countries. Additionally, the quality of the pirated movies available for downloading from peer-to-peer network increases following the American theatrical debut. A lag in the theatrical international release of movies gives time for better "telesync" copies or "screeners" to become available on peer-to-peer networks. Furthermore, official American DVDs were sometimes released while theater exhibition was still underway in international markets. ${ }^{11}$ Due to the strategy of releasing movies sequentially in global markets we might expect the file sharing displacement effect on theatrical attendance to be larger in international markets than in the US. It is therefore possible that downloads may have caused an equally large displacement of theatrical attendance.

\footnotetext{
${ }^{10}$ Blue-ray won the high definition format competition in 2008 when Toshiba withdrew its support for the HD DVD format.

${ }^{11}$ Exhibiting and releasing movies in theaters after the release of the DVD in the US has also been frequent in countries that are not included in our data sample. For example, comparing the DVDs available for rent at Blockbuster in the US and the movies playing at the most upscale Argentinean theaters (the theaters that release movies first within the country-Cinemark 8 Puerto Madero was used for comparison) in April 2010 shows that some of the movies playing in these theaters (and even some movies not yet released for the Argentinean market) were already available for rent in the US. Noting that movies are released sequentially across theaters within countries indicates that some theaters abroad will play several movies while highquality copies of these movies made from DVDs released in the US are available for downloading on peerto-peer networks.
} 
The clustering of international theatrical releases may have reduced the impact of file sharing on international theatrical attendance. Nevertheless, we should point out that simultaneous theatrical releases of movies in international markets might also have increased the availability of "telesync" copies on peer-to-peer networks made in countries with lower piracy control. In addition, although language does not appear to have been an impediment for sharing movies online, the clustering of releases in international markets might have made it easier to find "telesync" copies of movies in different languages. ${ }^{12}$

\section{III- Empirical Approach}

The introduction of file sharing technology provides individuals with a "zero" priced substitute for movies, although there is a non-monetary cost in time. File sharing might have therefore caused a leftward shift in the demand for paid movies. We are interested in gauging the impact of file sharing on the commercial performance of movies (both theatrical and video). We examine whether or not aggregate commercial theatrical and video performances have decayed more rapidly in countries experiencing faster increases in the adoption of file sharing technology. We do not postulate null hypotheses that file sharing has either a positive or negative effect on the movie industry, but instead allow the data to provide the answer. We begin by defining a fixed effect model of the following form:

$$
M P_{i t}=\beta F S_{i t}+\gamma X_{i t}+\alpha_{t}+\varphi_{i}+v_{i t}
$$

where $M P_{i t}$ stands for the commercial performance of movies in country $i$ and year $t$ (MP will represent theatrical, video rental, or video retail commercial performances). The variable $F S$ stands for the amount of movie file sharing, $X$ is a vector of country-level and time-varying controls, $\alpha_{t}$ is a year fixed effect, and $\varphi_{i}$ is a country fixed effect. These country fixed effects account for time invariant factors that may be specific to each country, for example the size, cultural mores, language, attitudes toward piracy, and level of organized piracy. Year fixed effects account for aggregate trends. By including year fixed effects, the identification in Model (1) arises from idiosyncratic variation in file sharing within countries from year to year, and not from aggregate variation in file sharing over time.

Model (1) cannot be estimated because country-level estimates of the amount of file sharing are not available. We will first assume that the relationship between the share of peer-to-peer users in the population and Internet penetration has the following form:

\footnotetext{
${ }^{12}$ Clustering international theatrical releases likely reduces the file sharing displacement effect on DVDs in international markets. This is because when DVD releases are not clustered copies can be made from original American DVDs and shared by international consumers once the American DVDs are released (international consumers can obtain DVDs before they are officially released in their countries). Clustering international theatrical releases may have made it easier for movie studios to cluster international DVD releases, because studios want to "window" theater and DVD movie releases within each country.
} 


$$
F S_{i t}=\lambda I_{i t}+\omega_{i t}
$$

where $I_{i t}$ is Internet penetration in country $i$ and year $t$. Equation (2) assumes that file sharing is proportional to the level of Internet penetration. Substituting (2) into (1) we obtain a model that can be estimated with the data available to us:

$$
M P_{i t}=\beta \lambda I_{i t}+\gamma X_{i t}+\alpha_{t}+\varphi_{i}+u_{i t}
$$

Our interest is in the size of the coefficient $\beta$ that measures the effect of file sharing on the commercial performance of movies. Using (3) we are able to estimate $\beta \lambda$. Under the assumption that the Internet can be correctly excluded from Model (1), $\beta \lambda$ is equivalent to the effect of file sharing on movie commercial performance up to a scale factor.

The identifying assumption for using Internet penetration as a proxy for file sharing in Model (3) would be that Internet penetration does not explain aggregate movie commercial performances for reasons unrelated to file sharing. The Internet may in itself be either a complement or a substitute for movie commercial performances for reasons unrelated to file sharing. For example, it is well known that the Internet has a promotional effect on movies through both word of mouth communication and by reducing consumers' search costs (see Yong Liu 2006 for an example). If these effects are positive (they might be negative), estimates of (3) would underestimate any negative impact of file sharing on the commercial performance of movies.

It is also plausible that the time individuals spend on the Internet is a substitute for the time they would otherwise employ watching movies. Individuals may not watch movie videos off-line (DVD or VHS) while they browse the web or may not go to the movie theater because they are otherwise entertained online (for reasons unrelated to file sharing). This is a typical concern in the literature on the impact of file sharing on music sales, but it is more relevant for movie videos. Listening to records, as a consumption experience, is different from watching videos in that record listening is not a foreground activity, which presumably allows individuals to multitask (i.e., listen to records while they browse the Internet). ${ }^{13}$ On the other hand, most uses of the Internet as well as watching videos off-line are foreground activities, and it is less likely that individuals are able to do both at the same time. If the Internet as an entertainment medium diverts consumers from watching videos off-line or going to the theater, then the exclusion of the Internet variable from Model (1) is invalid and using it as a proxy for file sharing would lead to an overestimation of the effect of file sharing on the commercial performance of movies. Any displacement of movie consumption due to the Internet as an entertainment medium itself would be incorrectly attributed to file sharing.

The Internet may therefore harm the commercial performance of movies due to both file sharing and acting as a competitive entertainment medium. It may enhance or harm performance due to any promotional effect and by reducing consumers' search costs. In

\footnotetext{
${ }^{13}$ This is not valid when individuals surf websites that carry sound (e.g. YouTube and Pandora).
} 
order to disentangle these effects we will employ an empirical framework using the speed of the adoption of broadband and the technological constraints restricting movie file sharing before 2003. We first introduce the speed of Internet connections into the analysis. A broadband connection is essential for downloading large files, but may not be required for acquiring information about movies or using the Internet as an entertainment medium. The following model:

$$
M P_{i t}=a_{1} I_{i t}+a_{2} B B_{i t}+\gamma X_{i t}+\alpha_{t}+\varphi_{i}+u_{i t}
$$

includes broadband penetration as an additional covariate. This model allows studying how the commercial performance of movies changes when increasing broadband penetration, while holding the level of Internet penetration fixed. Note that:

$$
I_{i t}=B B_{i t}+\text { Dial } U p_{i t}
$$

The coefficient $a_{2}$ in (4) then measures the effect on movie commercial performance of increasing broadband penetration replacing dial-up (from the previous equation dial-up Internet must decrease when increasing broadband Internet while holding total Internet penetration constant). If the change from having a dial-up connection to having a broadband connection does not add any additional word of mouth promotional effect or change the appeal of the Internet as an entertainment medium, then $a_{2}$ would measure the file sharing effect on the commercial performance of movies.

We believe that using broadband connectedness as a proxy for file sharing is reasonable; in particular we do not claim that broadband access and file sharing are perfectly correlated. There is substantial evidence both from the United States and Europe that individuals with access to a broadband connection increase the file sharing of music. For example: Rob and Waldfogel (2006) and Zentner (2006) use US and European broadband access as an instrument for individual level file sharing of music. The first stage regressions in both papers show that having a broadband connection substantially increases music downloading. A broadband connection is substantially more important in order to download large movie files than it is to download a smaller music file. It is practically impossible to download large movie files with dial-up connections. We can reasonably assume that individuals with no access to a broadband connection do not download movie files. If a panel of file sharing information by countries was available to us, which is not, we would probably still want to use changes in broadband access as an instrumental variable in order to deal with a particular endogeneity: individuals who download movies from file sharing networks are likely to have a greater taste for movies than other individuals. ${ }^{14}$

Model (4) is still invalid if high-speed connections have a different promotional impact than dial-up connections (e.g., they reduce the cost in search time), or if fast connections

\footnotetext{
${ }^{14}$ Note that using broadband access as an instrument for file sharing is not ideal, as explained in Zentner 2006. A potential shortcoming of using Internet and broadband as proxies or instruments for file sharing is that having an Internet or broadband connection is a choice for individuals and this choice may be potentially related to movie purchases.
} 
change the appeal of the Internet as an entertainment medium and induce individuals to spend more time online. ${ }^{15}$ It is also plausible that broadband adoption is correlated with unobservable variables excluded from our model that are in turn correlated with the commercial performance of movies. In this latter case, broadband connectedness will absorb the effect of unobservable confounding factors that have an impact on the commercial performance of movies.

Therefore, Model (4) may give spurious estimates of the file sharing effect for behavioral and statistical reasons (i.e., broadband has a direct effect on the commercial performance of movies for reasons unrelated to file sharing and broadband absorbs the effect of unobservable confounding factors). In order to correct for this bias, we distinguish two time periods and exploit the technological constraints limiting the amount of movie file sharing before the year 2003. We estimate two models:

$$
\begin{array}{ll}
M P_{i t}=a_{1}^{b} I_{i t}+a_{2}^{b} B B_{i t}+\gamma^{b} X_{i t}+\alpha_{t}^{b}+\varphi_{i}^{b}+u_{i t} & \text { for } \mathrm{t}<2003(5) \\
M P_{i t}=a_{1}^{a} I_{i t}+a_{2}^{a} B B_{i t}+\gamma^{a} X_{i t}+\alpha_{t}^{a}+\varphi_{i}^{a}+u_{i t} & \text { for } \mathrm{t} \geq 2003(6)
\end{array}
$$

Comparing the estimates from Models (5) and (6) allows us to isolate the effect of file sharing from any other behavioral impact of broadband, and from any other statistical effect of broadband on movie commercial performance that may arise from the correlation of broadband with unobservable variables excluded from Model (4). In particular, $a_{2}^{b}$ represents the broadband effect in the absence of file sharing because movie file sharing was negligible before 2003, and $a_{2}^{a}-a_{2}^{b}$ represents the file sharing effect on the commercial performance of movies (the supra-indexes $b$ and $a$ stand for before and after 2003 respectively). Our empirical strategy is therefore to measure the effect on the film industry of increasing broadband penetration replacing dial-up, and examine how that effect changed before and after the introduction of BitTorrent.

\section{IV-The Data}

This paper uses a panel of data at the country level in order to empirically examine whether and to what extent movie file sharing has an impact on the movie industry. We acquired data at the country level on the theatrical and video rental and retail commercial performance of movies. These data come from the European Audiovisual Observatory (a non-profit public service institution under the auspices of the Council of Europe with participation by the European Union) and the International Video Federation (representing video associations and individual companies in the US and several European countries). The data is presented in three databases. The first database is a

\footnotetext{
${ }^{15}$ It is unclear whether or not a broadband connection will induce individuals to spend more time online. On the one hand, individuals require less time to perform any given online activity. On the other, a highspeed connection likely induces individuals to increase the number of online activities they want to perform.
} 
panel for the years 1996 through 2008 containing information on theatrical revenues and the number of admission tickets sold for 36 countries, including most European countries, the US, and Japan. The second database is a panel for the years 2001 through 2008 containing information on the revenues from DVD sales (excluding VHS) for 24 countries, including many European countries, the US, and Japan. The third database is a panel for the years 2000 through 2008 with information on revenues from the retail and rental of videos (both DVDs and VHSs) for 18 countries, including once again several European countries and the US. Table 1 presents summary statistics.

Table 1

Global Movie Industry: Theaters and Videos

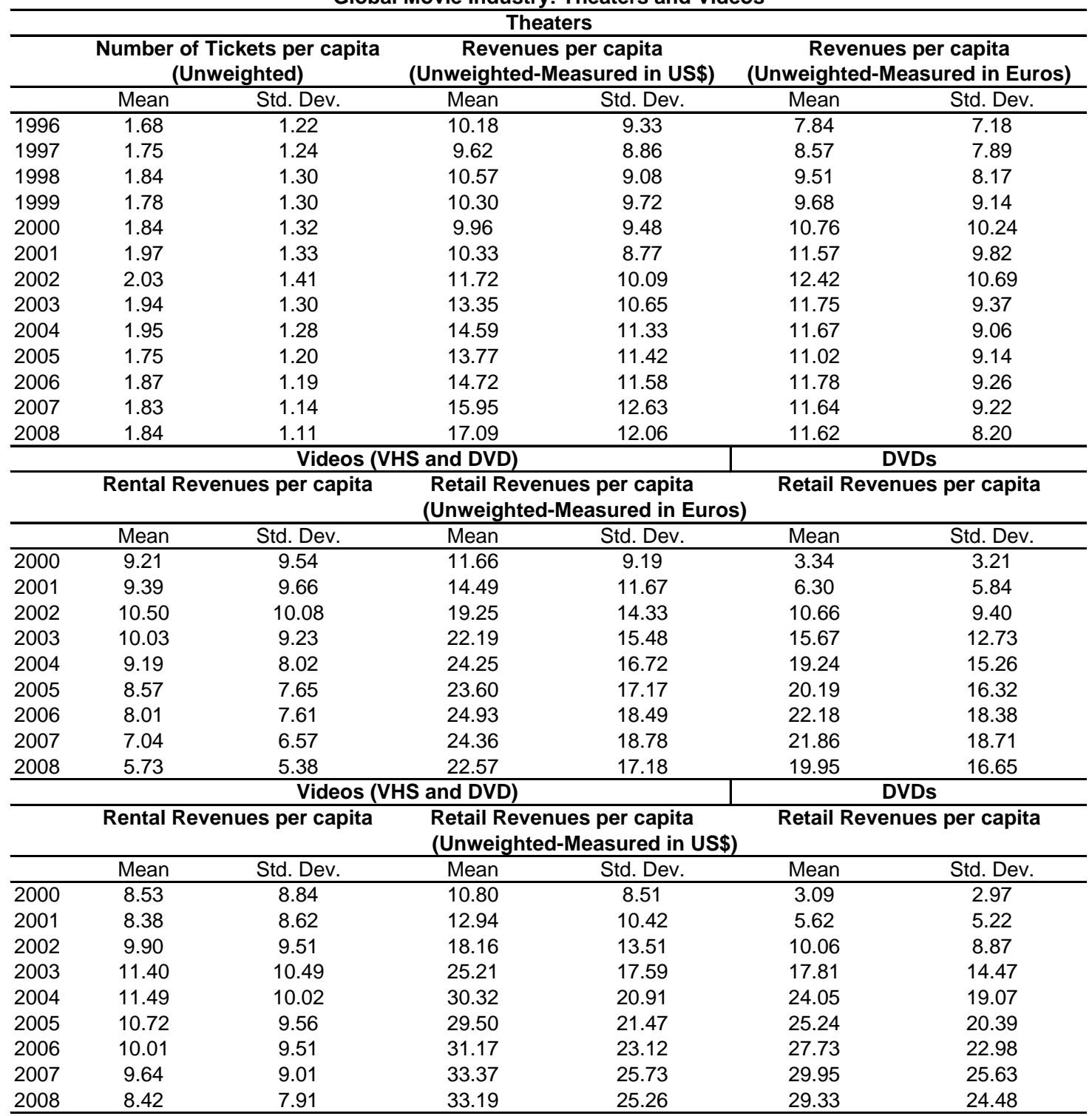

Source: European Audiovisual Observatory. Due to the unbalanced nature of the panel the statistics for the theatrical market are computed using information for 29 countries. The statistics on DVD retail revenues are computed using information for 18 countries in the year 2000 and 24 countries since 2001. The statistics on video retail revenues (including DVD and VHS) are computed using 18 countries and the statistics on video rental (including DVD and VHS) are computed using 17 countries.

The regressions below use information from all countries. 
Table 1 shows that the commercial theatrical performance of movies measured in tickets sold per capita increased until the year 2002 and then decayed. Exchange rate fluctuations make it difficult to examine the global trends in theatrical attendance measured using revenues per capita. Theatrical revenues increase rapidly until 2002 and then decrease when they are measured in Euros per capita. On the other hand, revenues reach a maximum in 2008 when they are measured in dollars per capita. For this reason, it will be important to include the exchange rate as a covariate in our regressions in order to control for the variation over time in the value of the dollar against other currencies. It should also be noted that the monetary values in Table 1 are not inflation adjusted, and therefore underestimate the decrease (overestimate the increase) in revenues. The regressions below will control for the inflation rate at the country level.

Global video rental revenues have decayed since 2002 measured in Euros per capita and since 2004 measured in dollars per capita. Revenue trends of total video sales and DVD sales alone leveled off when measured in dollars per capita (decayed measured in Euros) in the second half of the last decade, after having experienced a very substantial increase in the first half.

We combine the data on the movie industry with data on Internet and broadband usage by country from the International Telecommunication Union (ITU). ${ }^{16}$

Table 2

Online Connectedness

\begin{tabular}{|c|c|c|c|c|}
\hline & \multicolumn{2}{|c|}{ Internet Penetration } & \multicolumn{2}{|c|}{ Broadband Penetration } \\
\hline & Mean & Std. Dev. & Mean & Std. Dev. \\
\hline$\overline{1996}$ & 4.23 & 5.05 & 0.00 & 0.00 \\
\hline 1997 & 7.13 & 7.39 & 0.00 & 0.00 \\
\hline 1998 & 10.89 & 9.92 & 0.02 & 0.09 \\
\hline 1999 & 15.34 & 12.40 & 0.07 & 0.21 \\
\hline 2000 & 20.50 & 14.38 & 0.48 & 0.77 \\
\hline 2001 & 25.10 & 15.71 & 1.44 & 1.75 \\
\hline 2002 & 35.52 & 20.74 & 3.03 & 3.05 \\
\hline 2003 & 39.76 & 20.80 & 5.03 & 4.62 \\
\hline 2004 & 44.24 & 21.04 & 7.93 & 6.35 \\
\hline 2005 & 48.14 & 21.22 & 11.67 & 8.30 \\
\hline 2006 & 51.96 & 20.17 & 15.12 & 8.79 \\
\hline 2007 & 56.54 & 18.95 & 18.68 & 9.16 \\
\hline 2008 & 61.22 & 17.73 & 21.47 & 9.26 \\
\hline
\end{tabular}

Source: International Telecommunication Union. Computed using 36 countries.

\footnotetext{
${ }^{16}$ The ITU's broadband variable we use excludes mobile subscriptions. Mobile broadband with the capability to download large movie files was insignificant during the study period. It is feasible to download pirated copies of movies using the iPhone and other newer smartphones, but it was not feasible (from a practical standpoint) with older generation Internet-capable cell phones since their Internet and physical capability was primarily restricted to mobile email. The iPhone, however, was released in the US in 2007 and in Europe in 2008. In order to guarantee that our results are not contaminated by the growth in new generation smart-phone use (phones capable of downloading movies) that began in 2008 (2007 in the US), we ran regressions excluding year 2008 (excluding years 2007 and 2008 for the US). The results are similar to the results reported in the paper and are available on request.
} 
Table 2 shows that Internet and broadband penetration have increased steadily over the past decade. The data also reveals that Internet and broadband penetration across countries has large variation. Substantial idiosyncratic variation in the rates of Internet adoption provides a high contrast that is essential for identification.

Finally, we also use a panel of data including information on software piracy by country from the Business Software Alliance (BSA) (attempting to control for country-level changes in both police efforts and legal systems since changes in regulations and police efforts might have similar impacts on both movie and software physical piracy), and panels of data on GDP, population counts, exchange rates, and inflation from the World Bank and the International Monetary Fund. ${ }^{17}$ Table 3 shows some additional descriptive statistics.

Table 3

Additional Descriptive Statistics

\begin{tabular}{|c|c|c|c|c|c|c|}
\hline & \multicolumn{2}{|c|}{$\begin{array}{c}\text { Software Piracy } \\
\text { (Unweighted-fraction of lost revenues) }\end{array}$} & \multicolumn{2}{|c|}{$\begin{array}{l}\text { GDP per capita in US\$ } \\
\text { (Unweighted) }\end{array}$} & \multicolumn{2}{|c|}{$\begin{array}{l}\text { Population (in millions) } \\
\text { (Unweighted) }\end{array}$} \\
\hline & Mean & Std. Dev. & Mean & Std. Dev. & Mean & Std. Dev. \\
\hline 1996 & 0.59 & 0.20 & 18,857 & 14,162 & 30.3 & 54.1 \\
\hline 1997 & 0.55 & 0.19 & 17,924 & 13,129 & 30.4 & 54.5 \\
\hline 1998 & 0.52 & 0.20 & 18,588 & 13,773 & 30.5 & 54.9 \\
\hline 1999 & 0.49 & 0.18 & 18,938 & 14,217 & 30.7 & 55.3 \\
\hline 2000 & 0.47 & 0.17 & 18,163 & 13,726 & 30.9 & 55.7 \\
\hline 2001 & 0.46 & 0.16 & 18,132 & 13,612 & 31.0 & 56.1 \\
\hline 2002 & 0.44 & 0.16 & 19,843 & 14,793 & 31.1 & 56.5 \\
\hline 2003 & 0.44 & 0.16 & 23,982 & 17,777 & 31.3 & 56.8 \\
\hline 2004 & 0.44 & 0.17 & 27,701 & 20,678 & 31.4 & 57.2 \\
\hline 2005 & 0.43 & 0.17 & 29,509 & 21,899 & 31.6 & 57.5 \\
\hline 2006 & 0.42 & 0.16 & 31,676 & 23,800 & 31.7 & 57.9 \\
\hline 2007 & 0.41 & 0.16 & 36,631 & 27,446 & 31.8 & 58.2 \\
\hline 2008 & 0.40 & 0.15 & 40,766 & 31,828 & 32.0 & 58.6 \\
\hline
\end{tabular}

\section{V- Estimation Results}

\section{V-A- The Impact of File Sharing on the Commercial Performance of Movies in Theaters}

We first study the impact of file sharing on theatrical revenues measured in US dollars per capita. Table 4 presents Ordinary Least Squares estimation results. ${ }^{18}$ In addition to the

\footnotetext{
${ }^{17}$ Either including or excluding the software piracy variable in the regressions does not affect any of the estimates on the broadband variable. Software piracy is measured as the percentage of software sales lost due to piracy. A demand for new software is estimated using the number of personal computers (PCs) and an estimated ratio of software to PCs in the US market. The supply of software is estimated using shipment data for BSA member companies. Piracy is defined as the difference between software demand and software legally supplied. BSA members include producers of commercial software (Microsoft, Apple, Intel, and IBM among others). Exchange rates are measured in units of each foreign currency per US dollar. The inflation variable is a price index using the year 2000 as the base year.

${ }^{18}$ The appendix presents Huber robust regressions in order to account for outlier observations that may have an influential effect on the results. Our units of analysis, countries, are heterogeneous in size. One common discussion when studying units of analysis of heterogonous size is whether or not the observations should be weighted in the regressions using a measurement of their size (e.g. population). Weighting is
} 
Internet and broadband variables, the regressions include variables on income, exchange rate, inflation, population, and software piracy, as well as country and year fixed effects. It is important to include the exchange rate as a covariate in order to control for any idiosyncratic variation over time in the value of the US dollar against other currencies. We control for the inflation rate because the dependent variable is measured in current dollars and idiosyncratic trends in inflation might not be entirely captured by variations in the exchange rate. We include the software piracy rate as a covariate in an attempt to control for within country changes in both police efforts and legal systems; changes in regulations and police efforts might have similar impacts on movie and software physical piracy. Country fixed effects control for time invariant factors that may be specific to each country. Year fixed effects capture aggregate trends. Due to the inclusion of year fixed effects, the identification in our regressions arises from idiosyncratic variation in file sharing within countries from year to year, rather than from aggregate variation in file sharing over time.

The first column in Table 4 uses data for the years 1996 through 2002 and the second column uses data for the years 1998 through 2002. Since we do not have measurements on broadband penetration for the years 1996 and 1997 we assumed that for these years it was zero for all countries in the sample. The data for the years 1996 and 1997 therefore have no variation in broadband penetration across countries. We present regressions both including and excluding years 1996 and 1997 because we want to gauge how much of the identification in the regression in Column I arises from including these years with (assumed) zero broadband penetration in the analysis. In fact, for the years 1998 through 2002 both Columns I and II assume that broadband penetration in a country is zero when no measurement is available. This assumption might be reasonable because these measurements are likely missing when broadband penetration is actually zero or very low. Examining the data shows that countries had very low rates of broadband penetration (often below one percent) following the missing observations. Nevertheless, in Column III we do not assume that broadband is zero when the data is missing.

The first two columns show that the estimate of the coefficient $a_{1}^{b}$ in Model (5), measuring the effect of an increase in Internet penetration on theatrical revenues for the pre-file sharing of movies period, is not statistically significant. These regressions also show that the coefficient $a_{2}^{b}$ in Model (5) is positive, indicating that increasing broadband penetration in the pre-file sharing period, while holding the level of Internet penetration fixed, raises theatrical revenues. This positive impact of broadband in a period when the file sharing of movies was negligible has two possible explanations. First, this finding is consistent with high-speed connections having a larger promotional effect through word of mouth communication and reducing consumers' search costs than low-speed connections. The second explanation is that broadband connectedness might be positively

warranted and leads to gains in efficiency when observations have heterogeneous variance. In our case, giving greater weight to large countries would be preferable if for some reason information from large countries had lower variance and therefore data from large countries were more informative than data from small countries. We should not use weighted regressions in our study because there are no reasons to believe that the observations from different countries are not equally informative. The thought experiment of our study is to treat each country as a trial in a laboratory where each observation receives a treatment. 
correlated with unobservable variables excluded from our model that are in turn positively correlated with movie theatrical revenues. Broadband might therefore be capturing the effect of unobservable variables that have a positive impact on theatrical revenues. The third column excludes observations when broadband penetration is missing. This column also shows a positive broadband impact, although it is not statistically significant.

The sizes of the estimates of the broadband coefficient in Columns I through III suggest that an increase in broadband penetration from zero to one hundred percent would raise theatrical revenues per capita by US\$25.8, US\$19.5, and US\$15.2 respectively. These (unreasonably) large predicted impacts are out-of-the-sample extrapolations since broadband connectedness was, of course, substantially lower than one hundred percent between the years 1996 and 2002. We can make use of the actual rates of broadband connectedness in order to compute the actual predicted impact within the sample. Broadband penetration amounted to 3.03 percent in 2002. According to Column I (Column II and Column III) broadband increased theatrical revenues by US $\$ 0.78$ (US\$0.59 and US\$0.46), which translates to $8.3 \%(6.2 \%$ and $4.1 \%$ ) of the average revenues per capita for the observations in each sample.

Table 4

OLS Regressions on Theatrical Revenues (US\$ per capita)

\begin{tabular}{|c|c|c|c|c|}
\hline & $\begin{array}{l}\text { Years } 1996 \text { Through } \\
2002 \text { (broadband } \\
\text { assumed to be zero } \\
\text { when missing ) } \\
\text { I }\end{array}$ & $\begin{array}{l}\text { Years } 1998 \text { Through } \\
2002 \text { (broadband } \\
\text { assumed to be zero } \\
\text { when missing ) } \\
\text { II }\end{array}$ & $\begin{array}{c}\text { Years } 1998 \\
\text { Through } \\
2002 \\
\text { III }\end{array}$ & $\begin{array}{c}\text { Years } 2003 \\
\text { Through } \\
2008 \\
\text { IV }\end{array}$ \\
\hline Internet Penetration & $\begin{array}{l}-0.0255 \\
(0.0213)\end{array}$ & $\begin{array}{c}0.0066 \\
(0.0183)\end{array}$ & $\begin{array}{c}0.0198 \\
(0.0195)\end{array}$ & $\begin{array}{l}0.1143^{\star * \star} \\
(0.0399)\end{array}$ \\
\hline Broadband Penetration & $\begin{array}{l}0.2588^{* *} \\
(0.1223)\end{array}$ & $\begin{array}{l}0.1956^{*} \\
(0.1027)\end{array}$ & $\begin{array}{c}0.1529 \\
(0.1379)\end{array}$ & $\begin{array}{c}0.0021 \\
(0.0517)\end{array}$ \\
\hline GDP per capita & $\begin{array}{c}366.3322^{* * *} \\
(71.9891)\end{array}$ & $\begin{array}{c}430.3630 * * * \\
(84.7700)\end{array}$ & $\begin{array}{c}552.4432^{* * *} \\
(141.1878)\end{array}$ & $\begin{array}{c}314.6493^{* * *} \\
(54.7463)\end{array}$ \\
\hline Exchange Rate (in Logarithm) & $\begin{array}{l}-0.7689 \\
(0.7430)\end{array}$ & $\begin{array}{c}0.967 \\
(1.2049)\end{array}$ & $\begin{array}{c}2.309 \\
(3.0024)\end{array}$ & $\begin{array}{l}-3.3895 \\
(2.2452)\end{array}$ \\
\hline Price Index & $\begin{array}{c}0.0039 \\
(0.0108)\end{array}$ & $\begin{array}{l}-0.0071 \\
(0.0140)\end{array}$ & $\begin{array}{l}-0.0178 \\
(0.0139)\end{array}$ & $\begin{array}{l}0.0116^{*} \\
(0.0067)\end{array}$ \\
\hline Population (in Millions) & $\begin{array}{l}0.2154^{* * *} \\
(0.0672)\end{array}$ & $\begin{array}{c}0.2748^{* * *} \\
(0.0822)\end{array}$ & $\begin{array}{c}0.3794^{* * *} \\
(0.1000)\end{array}$ & $\begin{array}{c}0.0864 \\
(0.0971)\end{array}$ \\
\hline $\begin{array}{l}\text { Software Piracy } \\
\text { (Fraction of Lost Revenues) }\end{array}$ & $\begin{array}{l}1.8415 \\
(2.4339)\end{array}$ & $\begin{array}{c}1.0748 \\
(3.0060)\end{array}$ & $\begin{array}{c}1.6024 \\
(3.8134)\end{array}$ & $\begin{array}{l}-3.9926 \\
(6.0933)\end{array}$ \\
\hline $\begin{array}{l}\text { Observations } \\
\text { R-Squared }\end{array}$ & $\begin{array}{c}211 \\
0.9758\end{array}$ & $\begin{array}{c}154 \\
0.9873\end{array}$ & $\begin{array}{c}89 \\
0.995\end{array}$ & $\begin{array}{c}191 \\
0.9905\end{array}$ \\
\hline
\end{tabular}

Notes: The regressions include country and year fixed effects.

Robust standard errors in parentheses. * significant at 10\%; ${ }^{* *}$ significant at $5 \%$; ${ }^{* *}$ significant at $1 \%$

As argued before, the sharing of movies on peer-to-peer networks was very limited before 2003 due to the existing technological constraints. The regressions results presented in Column IV of Table 4 study the period beginning in 2003, when movie file sharing was revolutionized by the introduction of the BitTorrent protocol. The results contrast with those presented in the first three columns. This column shows that total 
Internet penetration had a positive impact on theatrical movie revenues, but the effect of broadband penetration was zero.

The regressions in Table 4 show that the effect of broadband on the box-office performance of movies was positive and large when the file sharing of movies was not feasible from any practical point of view. The effect of broadband is zero when technological innovations made the file sharing of movies a real alternative for consumers. As explained in Section III, the size of the file sharing effect can be computed by subtracting the coefficient for the post-movie file sharing period from the coefficient in the pre-file sharing period. Performing this exercise with the estimates from Table 4 suggests that file sharing may have caused a large reduction in theatrical movie revenues. Using the theatrical revenue levels of the year 2008 as a base year for comparison, the regressions for the pre-file sharing period predict that in the absence of file sharing boxoffice revenues would have (ceteris paribus) been higher by a magnitude ranging from 14 to 23 percent due to the increase in broadband penetration. Since the estimate of the broadband coefficient is (approximately) zero following the introduction of the new file sharing technology, by combining the estimates from both periods we find that file sharing may have (ceteris paribus) also caused a decay in theatrical revenues ranging from 14 and 23 percent of the revenue level in $2008 .^{19}$

The coefficient on the total Internet penetration variable in Column IV of Table 4 is positive and different from the coefficients in the first three columns. The Huber-robust counterparts in the appendix are, however, substantially different. More generally, across all regressions and for every market we study (theaters, video rental, and video sales) the coefficient on the total Internet variable changes widely and unsystematically across regressions and with changes in the specification. The coefficient on the Internet penetration variable measures the effect of increasing total Internet penetration while holding broadband constant; this is equivalent to changes in dial-up Internet unrelated to changes in broadband penetration $(I=B B+$ Dial-Up $)$. However, changes in dial-up penetration unrelated to broadband penetration changes are unusual during the study period. Changes in dial-up connections during our study period were primarily decreases in dial-up connections associated with increases in broadband connections. Thus, without increases in dial-up unrelated to increases in broadband the coefficient measuring the effect of dial-up on movie performance cannot be empirically identified. Because there is not enough variation in the data to empirically identify the effect of dial-up Internet (holding broadband constant), we do not believe it is surprising that the estimates on the coefficients on the total Internet penetration variable vary both substantially and unsystematically across regressions and specifications.

\footnotetext{
${ }^{19}$ Using the coefficients from Columns I (Columns II and Columns III) of Table 4 we can predict that, in the absence of file sharing, box-office revenues in 2008 would be have been approximately US $\$ 4.0$ (US\$3.1 and US\$2.5) higher due to the increase in broadband penetration. This is computed by multiplying the coefficients on broadband $0.25,0.19$ or 0.15 times 16.37 (21.4 minus 5.03) which is the change in the level of broadband penetration between 2003 and 2008. For comparison, revenues were US\$17.08 per capita in 2008. Subtracting the broadband impact coefficient for the post-movie file sharing period $(0.002)$ from $0.25,0.19$, and 0.15 and multiplying by 16.37 provides the file sharing impact.
} 
Although we pointed out above certain reasons to believe that (particularly in international markets) file sharing may have a strong effect on theatrical revenues, caution is warranted in the interpretation of this result. By using the estimates from Columns I, II, and IV of Table 4 we can reject the hypothesis that the broadband coefficients before and after the introduction of the file sharing technology are equal. However, due to the wide confidence intervals our estimates are also consistent with a much smaller file sharing impact. Additionally, we cannot reject the hypothesis that the estimates in Columns III and IV of Table 4 are statistically different. Furthermore, the appendix shows (Table A1) that the Huber-robust counterparts to the results in Table 4 imply a substantially lower impact of file sharing on theatrical revenues. Finally, we should also anticipate that our estimates of the impact of file sharing on the number of admission tickets per capita will not provide conclusive results on whether or not the file sharing impact is negative.

In addition to the Internet and broadband penetration variables, the regressions in Table 4 include variables on the GDP per capita, exchange rate, inflation, population, and software piracy. An increase in the GDP per capita increases theatrical revenues. The other covariates do not have a consistent impact. The appendix shows robustness checks when excluding some of these additional covariates.

Table 5 studies the impact of file sharing on the number of admission tickets per capita. As in Table 4, the first column in Table 5 uses data for the years 1996 through 2002, the second column uses data for years 1998 through 2002, and the third column does not assume that broadband is zero when no measurement is available. The estimated effect of broadband on the number of admissions per capita in Columns I, II, and III of Table 5 are not statistically significant and do not have a consistent sign. ${ }^{20}$

\footnotetext{
${ }^{20}$ On the other hand, the Huber-robust regressions that account for influential observations analogous to Columns I and II of Table 5 (presented in Table A2 in the appendix) give estimates of the broadband impact in the pre-movie file sharing period that are positive, large in size, and statistically significant. The appendix also shows that the Huber-robust estimate of the broadband impact analogous to the OLS estimate in Column III of Table 5 is both small and not statistically significant.
} 
Table 5

OLS Regressions on Theatrical Admission (Number of Tickets per capita)

\begin{tabular}{|c|c|c|c|c|}
\hline & $\begin{array}{l}\text { Years } 1996 \text { Through } \\
2002 \text { (broadband } \\
\text { assumed to be zero } \\
\text { when missing) } \\
\text { | }\end{array}$ & $\begin{array}{l}\text { Years } 1998 \text { Through } \\
2002 \text { (broadband } \\
\text { assumed to be zero } \\
\text { when missing) } \\
\text { II }\end{array}$ & $\begin{array}{c}\text { Years } 1998 \\
\text { Through } \\
2002 \\
\text { III }\end{array}$ & $\begin{array}{c}\text { Years } 2003 \\
\text { Through } \\
2008 \\
\text { IV }\end{array}$ \\
\hline Internet Penetration & $\begin{array}{l}0.0005 \\
(0.0027)\end{array}$ & $\begin{array}{l}0.0000 \\
(0.0028)\end{array}$ & $\begin{array}{l}-0.0001 \\
(0.0030)\end{array}$ & $\begin{array}{l}0.0067^{* *} \\
(0.0030)\end{array}$ \\
\hline Broadband Penetration & $\begin{array}{l}-0.0058 \\
(0.0146)\end{array}$ & $\begin{array}{c}0.0032 \\
(0.0112)\end{array}$ & $\begin{array}{l}-0.0081 \\
(0.0151)\end{array}$ & $\begin{array}{l}-0.0033 \\
(0.0052)\end{array}$ \\
\hline GDP per capita & $\begin{array}{c}1.5126 \\
(13.1085)\end{array}$ & $\begin{array}{c}18.4288 \\
(16.3707)\end{array}$ & $\begin{array}{c}23.5086 \\
(16.1289)\end{array}$ & $\begin{array}{l}-4.3874 \\
(3.6326)\end{array}$ \\
\hline Exchange Rate (in Logarithm) & $\begin{array}{c}0.1392 \\
(0.1147)\end{array}$ & $\begin{array}{l}0.4923^{* *} \\
(0.1923)\end{array}$ & $\begin{array}{l}1.0685^{\star *} \\
(0.4631)\end{array}$ & $\begin{array}{l}-0.1936 \\
(0.1824)\end{array}$ \\
\hline Price Index & $\begin{array}{l}-0.0057^{* *} \\
(0.0023)\end{array}$ & $\begin{array}{l}-0.0067^{* * *} \\
(0.0023)\end{array}$ & $\begin{array}{l}-0.0062^{* * *} \\
(0.0021)\end{array}$ & $\begin{array}{l}0.0026^{* * *} \\
(0.0007)\end{array}$ \\
\hline Population (in Millions) & $\begin{array}{l}0.0164^{*} \\
(0.0084)\end{array}$ & $\begin{array}{c}0.0026 \\
(0.0129)\end{array}$ & $\begin{array}{c}-0.001 \\
(0.0185)\end{array}$ & $\begin{array}{c}-0.0457^{* * *} \\
(0.0106)\end{array}$ \\
\hline $\begin{array}{l}\text { Software Piracy } \\
\text { (Fraction of Lost Revenues) }\end{array}$ & $\begin{array}{l}-0.3315 \\
(0.4543)\end{array}$ & $\begin{array}{l}-0.2666 \\
(0.4911)\end{array}$ & $\begin{array}{c}0.6717 \\
(0.6250)\end{array}$ & $\begin{array}{l}-0.3239 \\
(0.6106)\end{array}$ \\
\hline $\begin{array}{l}\text { Observations } \\
\text { R-Squared }\end{array}$ & $\begin{array}{l}218 \\
0.9814\end{array}$ & $\begin{array}{c}158 \\
0.991\end{array}$ & $\begin{array}{c}89 \\
0.9962\end{array}$ & $\begin{array}{c}202 \\
0.9911\end{array}$ \\
\hline
\end{tabular}

Notes: The regressions include country and year fixed effects.

Robust standard errors in parentheses. * significant at $10 \%$; ${ }^{* *}$ significant at $5 \%$; ${ }^{* *}$ significant at $1 \%$

Column IV of Table 5 shows the regression on the number of tickets sold per capita for the post-movie file sharing period. As with the estimates for the pre-file sharing period, the estimate of the broadband impact for the post-movie file sharing period is not statistically significant. When combining the estimates from the pre-file sharing and postfile sharing periods, Table 5 does not provide conclusive results for the impact of file sharing on the number of tickets sold. ${ }^{21}$

The regressions in Table 5 also include variables on the total Internet penetration, GDP per capita, exchange rate, inflation, population, and software piracy. Unlike Table 4, an increase GDP per capita does not have a consistent positive impact when the dependent variable is the number of tickets sold per capita. The remaining covariates do not have a consistent effect. ${ }^{22}$

In summary, taken together our results for the file sharing impact on theatrical revenues and the number of movie tickets sold do not provide confidence regarding the effect of file sharing on the theatrical commercial performance of movies.

\footnotetext{
${ }^{21}$ The Huber-robust estimates counterparts in the appendix show a negative effect of file sharing on the number of tickets sold (Table A2).

${ }^{22}$ Note that the coefficient on the total Internet penetration variable in Table 5 changes from being approximately zero in the pre-2003 period to being positive, although such a change is not observed in the Huber-robust counterparts in the appendix (Table A2). These abrupt changes signals the lack of identification of the total Internet variable in a period when broadband adoption replacing dial-up was the primary driver of the increase in Internet penetration.
} 
Table 6 studies the impact of file sharing on video rentals measured in US dollars per capita. As explained in Section IV the data on video rentals includes revenues from the rentals of both DVDs and VHSs and is available for only 18 countries. The first two columns present OLS and Huber-robust regressions using data for the years 2000 and 2002, and the last two present analogous regressions for the years 2003 through 2008.

Table 6

OLS and Huber Robust Regressions on Video Rental Revenues (US\$ per capita)

\begin{tabular}{|c|c|c|c|c|}
\hline & \multicolumn{2}{|c|}{ Years 2000 Through 2002} & \multicolumn{2}{|c|}{ Years 2003 Through 2008} \\
\hline & $\underset{\text { I }}{\text { OLS }}$ & $\begin{array}{c}\text { Huber Robust } \\
\text { II }\end{array}$ & $\begin{array}{l}\text { OLS } \\
\text { III }\end{array}$ & $\begin{array}{c}\text { Huber Robust } \\
\text { IV }\end{array}$ \\
\hline Internet Penetration & $\begin{array}{l}0.2120^{\star \star \star} \\
(0.0757)\end{array}$ & $\begin{array}{l}0.0222^{* *} \\
(0.0104)\end{array}$ & $\begin{array}{l}-0.1179 \\
(0.0934)\end{array}$ & $\begin{array}{c}-0.011 \\
(0.0335)\end{array}$ \\
\hline Broadband Penetration & $\begin{array}{c}0.2238 \\
(0.1857)\end{array}$ & $\begin{array}{l}0.2977^{* * *} \\
(0.0417)\end{array}$ & $\begin{array}{c}0.0527 \\
(0.1286)\end{array}$ & $\begin{array}{l}-0.0778 \\
(0.0557)\end{array}$ \\
\hline GDP per capita & $\begin{array}{c}-23.4999 \\
(363.5280)\end{array}$ & $\begin{array}{l}-53.7228 \\
(61.5909)\end{array}$ & $\begin{array}{l}-509.5919^{* * *} \\
(154.8049)\end{array}$ & $\begin{array}{l}-172.0649^{* * *} \\
(36.1170)\end{array}$ \\
\hline Exchange Rate (in Logarithm) & $\begin{array}{l}-25.5891^{\star} \\
(12.8560)\end{array}$ & $\begin{array}{l}6.2964^{* * *} \\
(2.1208)\end{array}$ & $\begin{array}{l}-6.2802 \\
(9.9762)\end{array}$ & $\begin{array}{c}2.9557 \\
(3.6814)\end{array}$ \\
\hline Price Index & $\begin{array}{c}0.0506 \\
(0.1725)\end{array}$ & $\begin{array}{l}0.1978^{* * *} \\
(0.0321)\end{array}$ & $\begin{array}{c}-0.083 \\
(0.0890)\end{array}$ & $\begin{array}{l}-0.1033^{*} \\
(0.0523)\end{array}$ \\
\hline Population (in Millions) & $\begin{array}{l}-0.3277^{*} \\
(0.1722)\end{array}$ & $\begin{array}{l}-0.5212^{* * *} \\
(0.0619)\end{array}$ & $\begin{array}{l}-0.6026^{* *} \\
(0.2440)\end{array}$ & $\begin{array}{c}-0.6048^{\star \star *} \\
(0.1110)\end{array}$ \\
\hline $\begin{array}{l}\text { Software Piracy } \\
\text { (Fraction of Lost Revenues) }\end{array}$ & $\begin{array}{c}-7.541 \\
(12.4591)\end{array}$ & $\begin{array}{l}-2.6057 \\
(2.7029)\end{array}$ & $\begin{array}{c}-26.655 \\
(23.7974)\end{array}$ & $\begin{array}{c}12.8053 \\
(10.1597)\end{array}$ \\
\hline Observations & 54 & 53 & 104 & 104 \\
\hline R-Squared & 0.9876 & 0.9997 & 0.972 & 0.9936 \\
\hline
\end{tabular}

Notes: The regressions include country and year fixed effects.

Robust standard errors in parentheses. * significant at 10\%; ${ }^{* \star}$ significant at $5 \%$; ${ }^{* *}$ significant at $1 \%$

The OLS and Huber-robust estimates of the coefficients on the broadband variable show a larger broadband effect in the pre-movie file sharing period than in the post-file sharing period, but the OLS standard errors are very large and we cannot reject the hypothesis that the broadband coefficients in these two periods are equal. The point estimates suggest that file sharing has a very large negative effect on video rentals. Based only on the size of the estimates (and ignoring the standard errors) the effect of file sharing on rentals in the OLS (Huber-robust) regressions is predicted to be US\$2.7 (US\$6.1) per capita. This is a substantial amount since rental revenues amounted to US\$11.5 per capita at their peak in 2004. Nevertheless, we cannot have much confidence in these results because the standard errors in the OLS are very large, and furthermore the size of the impact varies widely when using alternative specifications. For example, the OLS estimates for the broadband coefficients for the pre-file sharing and post-file sharing periods are equal when excluding some covariates. The OLS results in Table A11 in the appendix actually imply on their face that file sharing increases video rentals, although the standard errors are too large to draw a conclusion. The appendix shows that the negative file sharing effect also vanishes when including the square of the GDP as an additional covariate in the regressions (Table A3). 
Table 6 shows negative correlations between the GDP per capita and video rentals and between population and video rentals. The additional covariates included in the regressions do not show any consistent impacts.

We may expect the effect of file sharing on video sales to be larger than the effect on rentals. Consumers might be more inclined to either download or buy movies they plan to watch several times than movies they plan to watch only once. There is a (non-monetary) cost of downloading movies (e.g., cost in time). Someone who downloads a movie will have a greater net benefit when this substitutes for a purchase than when it substitutes for a rental, because rentals are cheaper than purchases.

Tables 7 and 8 study the effect of file sharing on total videos sales (including VHSs and DVDs) and on DVD sales alone measured in dollars per capita. ${ }^{23}$ Columns I and II show OLS and Huber-robust regressions on total video sales and on DVD sales alone in the pre-movie file sharing period. Consistent with the results of the extant research (Smith and Telang 2008), we find that the impact of broadband before 2003 was positive and economically large. Broadband penetration amounted to 3.03 percent in 2002. The estimates in Columns I and II in Table 7 (Table 8) therefore indicate that, for reasons unrelated to file sharing, broadband penetration may have explained an increase in revenues from total videos sales (DVDs alone) ranging from US\$3.1 to US\$4.9 per capita (US\$2.2 and US\$3.8), or between 22 percent and 35 percent (34 percent and 59 percent) of the average total video (DVD) sales per capita during this period. As argued, this broadband impact might arise either because broadband has a direct effect on the commercial performance of movies for reasons unrelated to file sharing (e.g., search costs) or because the broadband variable absorbs the effect of unobservable confounding factors.

\footnotetext{
${ }^{23}$ The information on DVD sales is available for a larger number of countries than the information on total video sales. See Section IV.
} 
Table 7

OLS and Huber Robust Regressions on Video Sales Revenues (US\$ per capita)

\begin{tabular}{|c|c|c|c|c|}
\hline & \multicolumn{2}{|c|}{ Years 2000 Through 2002} & \multicolumn{2}{|c|}{ Years 2003 Through 2008} \\
\hline & $\underset{\text { I }}{\text { OLS }}$ & $\begin{array}{c}\text { Huber Robust } \\
\text { II }\end{array}$ & $\begin{array}{l}\text { OLS } \\
\text { III }\end{array}$ & $\begin{array}{c}\text { Huber Robust } \\
\text { IV }\end{array}$ \\
\hline Internet Penetration & $\begin{array}{c}0.1035 \\
(0.0881)\end{array}$ & $\begin{array}{c}0.0355 \\
(0.0241)\end{array}$ & $\begin{array}{c}0.0106 \\
(0.1832)\end{array}$ & $\begin{array}{c}-0.3981^{\star \star \star} \\
(0.0918)\end{array}$ \\
\hline Broadband Penetration & $\begin{array}{l}1.0535^{\star} \\
(0.5321)\end{array}$ & $\begin{array}{l}1.6224^{\star * *} \\
(0.1290)\end{array}$ & $\begin{array}{l}-0.0801 \\
(0.2442)\end{array}$ & $\begin{array}{c}0.0321 \\
(0.1419)\end{array}$ \\
\hline GDP per capita & $\begin{array}{c}1,078.9089^{* *} \\
(405.8332)\end{array}$ & $\begin{array}{l}918.9364^{* \star *} \\
(189.5624)\end{array}$ & $\begin{array}{c}1,492.4164^{\star \star *} \\
(220.6795)\end{array}$ & $\begin{array}{l}1,111.8063^{* * *} \\
(98.4295)\end{array}$ \\
\hline Exchange Rate (in Logarithm) & $\begin{array}{c}2.3258 \\
(22.3430)\end{array}$ & $\begin{array}{c}-17.5493^{\star \star *} \\
(6.2779)\end{array}$ & $\begin{array}{l}-7.5344 \\
(15.0004)\end{array}$ & $\begin{array}{c}-21.8435^{\star *} \\
(9.9365)\end{array}$ \\
\hline Price Index & $\begin{array}{l}-0.2741 \\
(0.3199)\end{array}$ & $\begin{array}{l}-0.0799 \\
(0.1007)\end{array}$ & $\begin{array}{l}0.4667^{* \star} \\
(0.1897)\end{array}$ & $\begin{array}{l}0.4496^{* * *} \\
(0.1404)\end{array}$ \\
\hline Population (in Millions) & $\begin{array}{l}0.8925^{\star * *} \\
(0.2611)\end{array}$ & $\begin{array}{l}0.8986^{\star * *} \\
(0.1938)\end{array}$ & $\begin{array}{l}-0.4311 \\
(0.4125)\end{array}$ & $\begin{array}{l}-1.0427^{\star \star \star} \\
(0.2945)\end{array}$ \\
\hline $\begin{array}{l}\text { Software Piracy } \\
\text { (Fraction of Lost Revenues) }\end{array}$ & $\begin{array}{c}9.6067 \\
(20.5935)\end{array}$ & $\begin{array}{c}5.9621 \\
(8.4459)\end{array}$ & $\begin{array}{l}-45.7056 \\
(40.7342)\end{array}$ & $\begin{array}{l}-24.4323 \\
(25.6537)\end{array}$ \\
\hline $\begin{array}{l}\text { Observations } \\
\text { R-Squared }\end{array}$ & $\begin{array}{c}54 \\
0.9806\end{array}$ & $\begin{array}{c}54 \\
0.9978\end{array}$ & $\begin{array}{c}108 \\
0.9788\end{array}$ & $\begin{array}{c}108 \\
0.9907\end{array}$ \\
\hline
\end{tabular}

Notes: The regressions include country and year fixed effects.

Robust standard errors in parentheses. ${ }^{*}$ significant at $10 \% ;{ }^{* *}$ significant at $5 \% ;{ }^{* * *}$ significant at $1 \%$

Table 8

OLS and Huber Robust Regressions on DVD Sales Revenues (US\$ per capita)

\begin{tabular}{|c|c|c|c|c|}
\hline & \multicolumn{2}{|c|}{ Years 2000 Through 2002} & \multicolumn{2}{|c|}{ Years 2003 Through 2008} \\
\hline & $\underset{I}{\text { OLS }}$ & $\begin{array}{c}\text { Huber Robust } \\
\text { || }\end{array}$ & $\begin{array}{l}\text { OLS } \\
\text { III }\end{array}$ & $\begin{array}{c}\text { Huber Robust } \\
\text { IV }\end{array}$ \\
\hline \multirow{2}{*}{ Internet Penetration } & 0.1164 & $0.0603^{\star * \star}$ & 0.0806 & $-0.1823^{\star \star}$ \\
\hline & $(0.1112)$ & $(0.0208)$ & $(0.1503)$ & $(0.0821)$ \\
\hline \multirow[t]{2}{*}{ Broadband Penetration } & 0.7505 & $1.2740^{\star * \star}$ & 0.1633 & $0.2757^{*}$ \\
\hline & $(0.6360)$ & $(0.1170)$ & $(0.2070)$ & $(0.1403)$ \\
\hline \multirow[t]{2}{*}{ GDP per capita } & $1,258.0822^{* *}$ & $999.8776^{\star * *}$ & $1,528.0401^{* * *}$ & $1,216.7999^{\star * \star}$ \\
\hline & $(483.1718)$ & $(160.9909)$ & (206.2953) & $(106.7148)$ \\
\hline \multirow[t]{2}{*}{ Exchange Rate (in Logarithm) } & 25.4412 & 4.0558 & $17.3520^{*}$ & 0.7025 \\
\hline & $(23.7474)$ & $(4.8558)$ & $(10.2816)$ & $(6.7148)$ \\
\hline \multirow[t]{2}{*}{ Price Index } & -0.2015 & $0.1194^{* *}$ & 0.035 & 0.047 \\
\hline & $(0.2390)$ & $(0.0559)$ & $(0.0531)$ & $(0.0499)$ \\
\hline \multirow[t]{2}{*}{ Population (in Millions) } & $1.7453^{* * *}$ & $2.0202^{* * *}$ & -0.3032 & $-1.0398^{\star * *}$ \\
\hline & $(0.2696)$ & $(0.1803)$ & $(0.3521)$ & $(0.2848)$ \\
\hline Software Piracy & 16.0734 & 4.9436 & -17.8365 & 16.6514 \\
\hline (Fraction of Lost Revenues) & (19.9089) & $(7.1167)$ & (26.9169) & (20.5744) \\
\hline Observations & 64 & 64 & 142 & 142 \\
\hline R-Squared & 0.9368 & 0.9944 & 0.9721 & 0.9857 \\
\hline
\end{tabular}

Notes: The regressions include country and year fixed effects.

Robust standard errors in parentheses. * significant at $10 \%$; ${ }^{* \star}$ significant at $5 \%$; ${ }^{\star \star \star}$ significant at $1 \%$

The OLS and Huber-robust estimates in Columns III and VI of Tables 7 and 8 show a stark contrast for the period beginning in 2003 compared with the estimates for the period before 2003. Increasing broadband penetration had no statistically significant impact on video revenues (including both VHS and DVD) or on DVD revenues alone in the period beginning in 2003, except in Column IV of Table 8. 
We can gauge the size of the effect of file sharing on video sales by comparing the regressions in the first two columns of Tables 7 and 8 with the regressions in the last two columns. The predicted file sharing effect from Table 7 (Table 8) ranges between US\$18.5 and US\$26 (US\$9.6 and US\$16.3) per capita. Table 1 showed that video retail revenues measured in US dollars increased rapidly in the first half of the past decade and then leveled off; total revenues from video sales amounted to US\$33.2 in 2008 and DVD revenues amounted to US\$29.3. Figure II shows both actual video sales and predicted video sales in the absence of file sharing using the OLS and Huber-robust estimates from Tables 7 and 8; the left panel shows total video sales including VHS and DVD and the right panel shows DVD sales. Our point estimates suggest that in the absence of file sharing revenues from video sales would have experienced a substantially larger increase than that observed. According to our point estimates, in the absence of file sharing video sales would have grown at a pace similar to that observed before the introduction of BitTorrent.

Figure II

Actual and Predicted Video Sales Trends (in US Dollars per capita) Total Video Sales

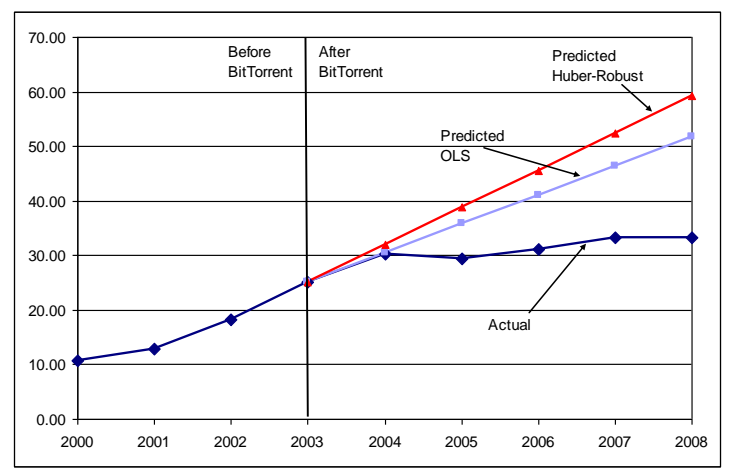

DVD Sales

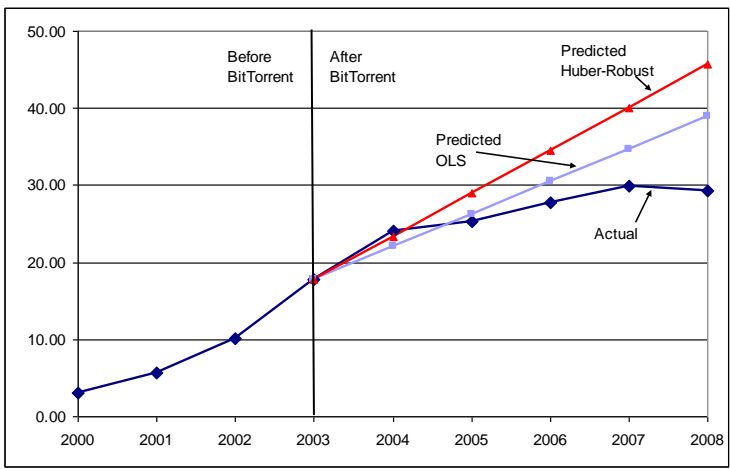

Tables 7 and 8 show a positive correlation between the GDP per capita measured at current prices and the dependent variables. The additional covariates included in these regressions have no consistent impacts.

Summarizing, our results suggest that movie file sharing has a negative and large impact on video sales. This result is robust to the alternative model specifications presented in the appendix (Tables A7, A8, A13, and A14). However, we do not have confidence regarding the impact of file sharing on video rentals because the estimates vary widely when using alternative model specifications.

\section{VI- Challenges to the Identification Strategy}

Our empirical strategy aims to isolate the file sharing effect from any other possible Internet impacts on the commercial performance of movies unrelated to file sharing. This is accomplished by comparing the impacts of increased high-speed online connectedness conditional on the level of Internet penetration before and after the introduction of the 
BitTorrent protocol. In this section we analyze some factors that might be thought to challenge our identification strategy.

A negative trend in the effect of broadband on movie commercial performances that both is unrelated to file sharing and would have existed even in the absence of BitTorrent might bias our results. For example, if the broadband effect on video sales unrelated to file sharing (conditional on total Internet penetration) is, for some reason, becoming more negative over time, then comparing the average effect of broadband before and after 2003 would show that the broadband effect is more negative after 2003 than before 2003 . Additionally, our results could be explained by a change in the broadband effect occurring several years after the introduction of BitTorrent and being unrelated to the introduction of BitTorrent. We now study whether or not our results can be explained by both a continuation of a trend in the effect of broadband unrelated to file sharing or other events occurring several years after the introduction of BitTorrent. We restrict our analysis to the effect of file sharing on video sales because we do not have confidence on the basic results presented above for either theatrical commercial performance or video rentals.

In Table 9 we study the pre-BitTorrent years. We run regressions identical to those presented in Tables 7 and 8 (only showing the coefficient on the broadband variable in order to save space).$^{24}$ There are only three pre-BitTorrent years available in the database for total video sales and DVD sales alone. Table 9 shows that there is no consistent change in the trend of the effect of broadband on video sales during the pre-BitTorrent period. For both DVD sales alone and total video sales, the broadband effect in the OLS regressions is higher (more positive) using only the years 2001 and 2002 relative to the estimates using 2000, 2001, and 2002. Comparing the Huber robust-estimates using only the years 2001 and 2002 relative to the estimates using 2000, 2001, and 2002, they increase for DVD sales alone but decrease for total video sales.

Table 9

Pre-BitTorrent Years DVD Sales

\begin{tabular}{|c|c|c|c|c|}
\hline \multicolumn{5}{|c|}{ DVD Sales } \\
\hline & \multicolumn{2}{|c|}{ Years 2001 and 2002} & \multicolumn{2}{|c|}{ Years 2000, 2001, and 2002} \\
\hline & OLS & Huber Robust & OLS & Huber Robust \\
\hline Broadband effect & $1.02(0.46)$ & $1.35(0.43)$ & $0.75(0.63)$ & $1.27(0.11)$ \\
\hline \multicolumn{5}{|c|}{ Total Video Sales (VHSs and DVDs) } \\
\hline & \multicolumn{2}{|c|}{ Years 2001 and 2002} & \multicolumn{2}{|c|}{ Years 2000, 2001, and 2002} \\
\hline Broadband effect & $\begin{array}{c}\text { OLS } \\
1.44(0.48)\end{array}$ & $\begin{array}{c}\text { Huber Robust } \\
1.45(1.28)\end{array}$ & $\begin{array}{c}\text { OLS } \\
1.05(0.53)\end{array}$ & $\begin{array}{c}\text { Huber Robust } \\
1.62(0.12)\end{array}$ \\
\hline
\end{tabular}

Regressions are analogous to those in Tables 7 and 8 . Robust standard errors in parentheses.

Table 10 presents the regressions for the post-BitTorrent period. For the post-BitTorrent period there is also no consistent change in the trend of the broadband effect on video sales. For both DVD sales alone and total video sales, using all years broadband has an effect that is higher (more positive) compared to the effect using the sub-period 20032006 but has a lower impact compared to the effect using the sub-period 2003-2005.

\footnotetext{
${ }^{24}$ The coefficients on the other variables are available on request.
} 
Table 10

Post-BitTorrent Years

\begin{tabular}{|c|c|c|c|c|c|c|}
\hline \multicolumn{7}{|c|}{ DVD Sales } \\
\hline & \multicolumn{2}{|c|}{ Years 2003 through 2006} & \multicolumn{2}{|c|}{ Years 2003, 2004, and 2005} & \multicolumn{2}{|c|}{ Years 2003 through 2008} \\
\hline & OLS & Huber Robust & OLS & Huber Robust & OLS & Huber Robust \\
\hline Broadband effect & $-0.14(0.30)$ & $0.11(0.21)$ & $0.29(0.32)$ & $0.65(0.16)$ & $0.16(0.20)$ & $0.27(0.14)$ \\
\hline \multicolumn{7}{|c|}{ Total Video Sales (VHSs and DVDs) } \\
\hline & \multicolumn{2}{|c|}{ Years 2003 through 2006} & \multicolumn{2}{|c|}{ Years 2003, 2004, and 2005} & \multicolumn{2}{|c|}{ Years 2003 through 2008} \\
\hline Broadband effect & $\begin{array}{c}\text { OLS } \\
-0.50(0.31)\end{array}$ & $\begin{array}{c}\text { Huber Robust } \\
-0.39(0.25)\end{array}$ & $\begin{array}{c}\text { OLS } \\
0.05(0.35)\end{array}$ & $\begin{array}{c}\text { Huber Robust } \\
0.17(0.23)\end{array}$ & $\begin{array}{c}\text { OLS } \\
-0.08(0.24)\end{array}$ & $\begin{array}{c}\text { Huber Robust } \\
0.03(0.14)\end{array}$ \\
\hline
\end{tabular}

In conclusion, although the period of study is likely too short to thoroughly analyze trends in the broadband effect, the additional regressions in Table 9 do not suggest that the broadband effect would have had either a positive or negative trend in the absence of BitTorrent. The regressions in Table 10 do not suggest that our post BitTorrent estimates mask a change in the broadband effect that occurred several years after the introduction of BitTorrent.

A second factor that might be thought to challenge our identification strategy is the growth in legal video downloads (e.g., streaming movies from Netflix); this is because both the rental and retail of video downloads require a broadband connection. It is important to emphasize that these technologies were introduced more recently and were negligible during our study period. Digital sales of movies in the United States amounted to US\$ 144.4 million in 2008, or $1.08 \%$ of the value of DVD sales. Digital rental spending in the US in 2008 amounted to US\$69.2 million, or $1.2 \%$ of rental revenues (Screen Digest). In Europe, rental and retail digital delivery combined amounted to only 40 million Euros in 2008 which is an even smaller percentage of video sales and rentals (Screen Digest). Netflix began renting movies via digital delivery in the US in 2007 but no comparable company existed in Europe (Lovefilm is today regarded as the Netflix of Europe). ${ }^{25}$

Nor do we believe that online games affect our estimates. A broadband connection is required in order to both play games online (massively multiplayer online games or MMOGs; e.g., "World of Warcraft") and illegally download movies online. If playing games online and watching movies are substitutes, which is not obvious but plausible, then the coefficient on the broadband variable would overestimate the file sharing effect. However, the empirics of the online gaming industry suggest that online gaming does not have an influence on our estimates. First, there was a relatively even growth in the number of players that began in 1998 before the creation of BitTorrent, implying that our pre-2003 regressions already capture this effect. Second, the number of online players in the countries in our sample was tiny, making it very unlikely that video revenues could be impacted to any measurable degree. ${ }^{26} 27$

\footnotetext{
${ }^{25}$ In order to guarantee that our results are not contaminated by the small amount of legal digital downloads we ran regressions excluding the year 2008 because in that year iTunes began offering digital movies in Europe (and also excluding the year 2007 data for the US since in 2007 Netflix streaming became available in the US). The results are similar to those reported in the paper and are available on request.

${ }^{26}$ The development of the online games industry began in 1998 and there were already more than four million global MMOG players in 2002 (http://www.mmodata.net/). There was a growth in the number of
} 
Cell phones use experienced very substantial growth during the study period but we do not believe the increase in cell phone use can affect our estimates. Liebowitz and Zentner (2010), while engaged in measuring the impact of the Internet on television viewing, studies whether or not cell phone use could explain a negative effect of the Internet on television viewing. Liebowitz and Zentner (2010) states, "since the major change in telephone talk time they (cell phones) might engender comes from their ability to allow calls to be made when the user is away from home and such mobile calls are not a replacement for television viewing. Nor are cell phones likely to increase the time talking at home since local cell phone calls are metered whereas local calls on landlines are not (although the existence of cell phones does allow individuals at home to speak to people who are outdoors, possibly increasing home-based talk time somewhat)." For similar reasons we do not believe that cell phones are likely to have an impact on movie viewing. Since our regressions control for total Internet use it is even less likely that cell phones would affect any of our estimates on the broadband variable.

\section{VII- Conclusion}

The study of whether or not file sharing affects the movie industry has received scant attention. This paper has examined the impact of file sharing on the movie industry. We have studied whether or not theatrical and video retail and rental commercial movie performances have decayed more rapidly in countries experiencing faster increases in the adoption of file sharing technologies. We have used online connectedness as a proxy for file sharing. In order to isolate the file sharing effect from other Internet effects unrelated to file sharing (e.g., promotional effect through word of mouth communication or confounding factors correlated with Internet connectedness), we have used an empirical strategy exploiting the speed of Internet connections and the technological constraints that limited the amount of movie file sharing before the year 2003. We have studied how broadband impacted the commercial performance of movies when movie file sharing was not yet feasible and whether or not this impact changed when technological innovations made movie file sharing a viable alternative.

\footnotetext{
players following the creation of BitTorrent, but it is just a continuation of a trend that began before the creation of BitTorrent. "World of Warcraft" is the most popular online game, representing $62.5 \%$ of all online gaming activity in 2008. This game was released in the second half of 2004 and there were ten million global users in 2008. Approximately 55\% of World of Warcraft users in 2008 were located in Asia, with only $20 \%$ of the users located in Europe. That means that $0.2(0.4)$ percent of the individuals in the European countries we include in our sample for the theatrical (video) regressions were World of Warcraft players in 2008. We ran regressions excluding Japan and the United States and the results are similar to the results presented in the text, these are available on request.

${ }^{27}$ Another possible candidate that might be thought to bias the results is video game consoles (off-line games). While video games might reduce movie viewing because they might compete for people's time, it is unclear either why or how not controlling for video games would bias our results on the broadband variable since we both control for total Internet use and compare before and after 2003. Using data from American cities Liebowitz and Zentner (2010) show that correlations between Internet penetration and videogame console penetration were negative, although not statistically significant.
} 
Our results indicate that in the absence of file sharing global video sales would have experienced an increase larger than that observed. Our paper therefore provides some evidence that appears to substantiate the concerns of movie studios regarding file sharing's potential for diminishing their revenues. However, we do not find conclusive results for the file sharing effect on either the theatrical or video rental commercial performance of movies. We have provided various reasons that seem to indicate that movie file sharing should be expected to displace video consumption to a greater extent than theatrical attendance (e.g., movie files on peer-to peer networks are usually of a better quality after the official release of the DVD than before this time). We have also argued that we would expect the effect of file sharing on video sales to be larger than the effect on rentals (consumers will be more inclined to either download or buy movies they plan to watch several times than movies they plan to watch only once). These factors might explain our finding that file sharing only affects video sales. ${ }^{28}$

Our study is of course not without limitations. First, due to promotional or other effects the speed of Internet connections (dial-up or broadband) may have different impacts on the commercial performance of movies in the absence of file sharing. In this case it would be difficult to disentangle the file sharing from other online connectedness effects on the commercial performance of movies. In addition, the quality and variety of Internet web sites, broadband speeds, and BitTorrent adoption rates may vary across time and countries in complicated and nonlinear ways. Although our regressions include fixed effects by countries and years, these factors and nonlinearities add a source of error to our results which are best interpreted as an approximation. Our findings are therefore subject to all the usual caveats found in empirical work of this type. In spite of these limitations we do believe that our analysis, methodology, and results contribute to the prior literature measuring the impact of file sharing on the sales of digital goods.

From a welfare standpoint, any increase in movie consumption caused by file sharing must be weighted against any reduction in movie creation attributed to the decline in the market due to file sharing. Complementary questions that future research will need to address are the extent to which a reduction in copyright value results in diminished artistic and cultural creations, and how file sharing affects the marketing of movies.

\section{References}

Bai, Jie and Waldfogel, Joel, "Movie Piracy and Sales Displacement in two Samples of Chinese Consumers," Working Paper, September 2009.

\footnotetext{
${ }^{28}$ An alternative identification strategy would have been to compare the effect of file sharing on video sales against the effect of file sharing on video rental and theatrical commercial performance.
} 
Bounie, David, Bourreau, Marc, and Waelbroeck, Patrick, "Piracy and the Demand for Films: Analysis of Piracy Behavior in French Universities," Review of Economic Research on Copyright Issues, 2006, 3 (2), 15-27

Boutin, Paul, "Meet BitTorrent, the file sharing network that makes trading movies a breeze", Slate, Feb 27, 2004. http://slate.msn.com/id/2096316/

Danaher, B., J. Waldfogel. 2012. Reel Piracy: The Effect of Online Movie Piracy on Film Box Office Sales. Working paper. http://papers.ssrn.com/sol3/papers.cfm?abstract id $=1986299$

Liebowitz, Stan and Zentner, Alejandro, "Clash of the Titans: Does Internet Use Reduce Television Viewing?," 2010, Forthcoming in The Review of Economics and Statistics.

Rob, Rafael and Waldfogel, Joel, "Piracy On The High C's: Music Downloading, Sales Displacement, And Social Welfare In A Sample Of College Students," Journal of Law and Economics, April 2006, pp. 29-62.

Rob, Rafael and Waldfogel, Joel, "Piracy On The Silver Screen," The Journal of Industrial Economics, Volume 55, Issue 3, 2007, pp. 379-395.

Screen Digest, http://www.screendigest.com/

Smith, Michael and Telang, Raul, "Piracy or Promotion? The Impact of Broadband Internet Penetration on DVD Sales," 2008, Working Paper.

US District Court, Northern District of California, Transcript of Proceedings, July 26, 2000

Waterman, David, Wook Ji, Sung, and Rochet, Laura, "Enforcement and Control of Piracy, Copying, and Sharing in the Movie Industry," Review of Industrial Organization, Vol. 30, No. 4, pp. 255-289.

Wired, "The BitTorrent Effect,” January 2005, Issue 13.01. http://www.wired.com/wired/archive/13.01/bittorrent.html

Yong (2006), Liu "Word-of-Mouth for Movies: Its Dynamics and Impact on Box Office Revenue," Journal of Marketing, 70 (3): 74-89.

Zentner, Alejandro, "Measuring The Effect Of File Sharing On Music Purchases," Journal of Law and Economics, April 2006, pp. 63-90.

Zentner, Alejandro, "Ten Years of File Sharing and Its Effect on International Physical and Digital Music Sales," August 2009, Working Paper. 


\section{Appendix $^{29}$}

This appendix presents additional analyses aimed at testing the robustness of the results presented above.

\section{Huber-Robust Estimates on the Commercial Theatrical Performance of Movies}

Tables A1 and A2 present Huber-robust regression estimates on theatrical revenues per capita and admissions tickets per capita respectively.

The estimates in Table A1 imply a substantially smaller impact of file sharing on theatrical revenues; the difference between the pre-file sharing and post file-sharing broadband impacts is not statistically different from zero.

29 Table 4 Column in the main text I uses data from Austria, Belgium, Bulgaria, Croatia, Cyprus, the Czech Republic, Denmark, Estonia, Finland, France, Germany, Hungary, Ireland, Italy, Japan, Latvia, Lithuania, Luxembourg, Malta, the Netherlands, Norway, Poland, Portugal, Romania, Russia, the Slovak Republic, Slovenia, Spain, Sweden, Switzerland, Turkey, the United Kingdom, and the United States. Table 4 Column IV uses data from same countries as Table 4 Column I except that data are not available from Luxembourg and are available for Ireland. Table 5 Column I uses data from same countries as Table 4 Column I except that it also uses data from Greece. Table 5 Column 4 uses data from same countries as Table 4 Column I except that it also uses data from Greece, Italy, and Macedonia. All the columns in Tables 6 and 7 use data from Belgium, Croatia, Denmark, Finland, France, Germany, Hungary, Ireland, Italy, the Netherlands, Norway, Poland, Portugal, Spain, Sweden, Switzerland, the United Kingdom, and the United States. Table 8 Columns I and II use data from Austria, Belgium, Croatia, the Czech Republic, Denmark, Finland, France, Germany, Greece, Hungary, Ireland, Italy, Japan, the Netherlands, Norway, Poland, Portugal, Russia, Spain, Sweden, Switzerland, the United Kingdom, and the United States. Table 8 Columns III and IV use data from same countries as Table 4 Columns I and II except that data are also available for Iceland. 
Table A1

Huber Robust Regressions on Theatrical Revenues (US\$ per capita)

\begin{tabular}{|c|c|c|c|c|}
\hline & $\begin{array}{l}\text { Years } 1996 \text { Through } \\
2002 \text { (broadband } \\
\text { assumed to be zero } \\
\text { when missing ) } \\
\text { I }\end{array}$ & $\begin{array}{l}\text { Years } 1998 \text { Through } \\
2002 \text { (broadband } \\
\text { assumed to be zero } \\
\text { when missing ) } \\
\text { II }\end{array}$ & $\begin{array}{l}\text { Years } 1998 \\
\text { Through } \\
2002 \\
\text { III }\end{array}$ & $\begin{array}{c}\text { Years } 2003 \\
\text { Through } \\
2008 \\
\text { IV }\end{array}$ \\
\hline Internet Penetration & $\begin{array}{l}-0.0129 \\
(0.0088)\end{array}$ & $\begin{array}{l}-0.0109 \\
(0.0098)\end{array}$ & $\begin{array}{c}0.0091 \\
(0.0119)\end{array}$ & $\begin{array}{l}0.0430^{\star *} \\
(0.0207)\end{array}$ \\
\hline Broadband Penetration & $\begin{array}{l}0.1078^{\star \star} \\
(0.0469)\end{array}$ & $\begin{array}{c}0.0672 \\
(0.0453)\end{array}$ & $\begin{array}{c}0.0469 \\
(0.0656)\end{array}$ & $\begin{array}{l}-0.0532 \\
(0.0384)\end{array}$ \\
\hline GDP per capita & $\begin{array}{c}424.9180^{* * *} \\
(31.1338)\end{array}$ & $\begin{array}{c}406.4971^{* * *} \\
(41.5775)\end{array}$ & $\begin{array}{l}351.1015^{\star * *} \\
(82.6765)\end{array}$ & $\begin{array}{l}216.7420^{* \star *} \\
(29.3292)\end{array}$ \\
\hline Exchange Rate (in Logarithm) & $\begin{array}{c}0.0243 \\
(0.3541)\end{array}$ & $\begin{array}{c}0.6764 \\
(0.7856)\end{array}$ & $\begin{array}{c}-1.944 \\
(2.2538)\end{array}$ & $\begin{array}{l}-2.9314^{*} \\
(1.5903)\end{array}$ \\
\hline Price Index & $\begin{array}{l}-0.0075 \\
(0.0062)\end{array}$ & $\begin{array}{c}-0.013 \\
(0.0084)\end{array}$ & $\begin{array}{l}-0.0043 \\
(0.0129)\end{array}$ & $\begin{array}{c}0.0116 \\
(0.0075)\end{array}$ \\
\hline Population (in Millions) & $\begin{array}{l}0.1770^{\star * *} \\
(0.0365)\end{array}$ & $\begin{array}{l}0.1940 * * * \\
(0.0503)\end{array}$ & $\begin{array}{l}0.5459^{* * *} \\
(0.0607)\end{array}$ & $\begin{array}{l}-0.0082 \\
(0.0820)\end{array}$ \\
\hline $\begin{array}{l}\text { Software Piracy } \\
\text { (Fraction of Lost Revenues) }\end{array}$ & $\begin{array}{c}1.0426 \\
(1.2214)\end{array}$ & $\begin{array}{c}1.117 \\
(1.6914)\end{array}$ & $\begin{array}{c}0.599 \\
(3.0186)\end{array}$ & $\begin{array}{c}3.0712 \\
(4.7693)\end{array}$ \\
\hline Observations & 211 & 154 & 87 & 191 \\
\hline R-Squared & 0.995 & 0.9965 & 0.9977 & 0.9947 \\
\hline
\end{tabular}

Notes: The regressions include country and year fixed effects.

Standard errors in parentheses. * significant at 10\%; ${ }^{* *}$ significant at $5 \%$; ${ }^{* *}$ significant at $1 \%$

The results from Columns I and II in Table A2 indicate that the file sharing impact computed using Huber-robust regressions estimates is negative and large. By combining the estimates in Columns I and II with the estimates in Column IV we find that file sharing reduced the number of tickets sold per capita by 0.42 and 0.33 tickets respectively. This represents $22 \%$ and $18 \%$ of the number of tickets sold per capita in 2008. 
Table A2

Huber Robust Regressions on Theatrical Admission (Number of Tickets per capita)

\begin{tabular}{|c|c|c|c|c|}
\hline & $\begin{array}{l}\text { Years } 1996 \text { Through } \\
2002 \text { (broadband } \\
\text { assumed to be zero } \\
\text { when missing ) }\end{array}$ & $\begin{array}{l}\text { Years } 1998 \text { Through } \\
2002 \text { (broadband } \\
\text { assumed to be zero } \\
\text { when missing ) }\end{array}$ & $\begin{array}{c}\text { Years } 1998 \\
\text { Through } \\
2002\end{array}$ & $\begin{array}{c}\text { Years } 2003 \\
\text { Through } \\
2008\end{array}$ \\
\hline & $\mathbf{I}$ & II & III & IV \\
\hline Internet Penetration & $\begin{array}{c}0.0000 \\
(0.0019)\end{array}$ & $\begin{array}{l}-0.0002 \\
(0.0018)\end{array}$ & $\begin{array}{l}-0.0031 \\
(0.0018)\end{array}$ & $\begin{array}{l}0.0027 \\
(0.0026)\end{array}$ \\
\hline Broadband Penetration & $\begin{array}{l}0.0225^{\star \star} \\
(0.0101)\end{array}$ & $\begin{array}{l}0.0167^{* *} \\
(0.0083)\end{array}$ & $\begin{array}{l}-0.0049 \\
(0.0102)\end{array}$ & $\begin{array}{l}-0.0035 \\
(0.0048)\end{array}$ \\
\hline GDP per capita & $\begin{array}{l}-11.0709 \\
(6.7004)\end{array}$ & $\begin{array}{l}-5.3458 \\
(7.5460)\end{array}$ & $\begin{array}{c}4.6942 \\
(12.7939)\end{array}$ & $\begin{array}{l}-4.3279 \\
(3.6129)\end{array}$ \\
\hline Exchange Rate (in Logarithm) & $\begin{array}{c}0.0021 \\
(0.0766)\end{array}$ & $\begin{array}{c}0.1357 \\
(0.1412)\end{array}$ & $\begin{array}{c}0.4422 \\
(0.3488)\end{array}$ & $\begin{array}{l}-0.4072^{* *} \\
(0.2005)\end{array}$ \\
\hline Price Index & $\begin{array}{l}-0.0013 \\
(0.0013)\end{array}$ & $\begin{array}{c}-0.002 \\
(0.0015)\end{array}$ & $\begin{array}{l}-0.0026 \\
(0.0020)\end{array}$ & $\begin{array}{l}0.0023^{* *} \\
(0.0009)\end{array}$ \\
\hline Population (in Millions) & $\begin{array}{l}0.0159 * * \\
(0.0079)\end{array}$ & $\begin{array}{c}0.0081 \\
(0.0092)\end{array}$ & $\begin{array}{c}-0.0361^{* \star *} \\
(0.0094)\end{array}$ & $\begin{array}{c}-0.0314^{\star * \star} \\
(0.0103)\end{array}$ \\
\hline $\begin{array}{l}\text { Software Piracy } \\
\text { (Fraction of Lost Revenues) }\end{array}$ & $\begin{array}{c}0.3132 \\
(0.2597)\end{array}$ & $\begin{array}{c}0.3361 \\
(0.2929)\end{array}$ & $\begin{array}{l}-0.4034 \\
(0.4671)\end{array}$ & $\begin{array}{l}-0.7901 \\
(0.5901)\end{array}$ \\
\hline $\begin{array}{l}\text { Observations } \\
\text { R-Squared }\end{array}$ & $\begin{array}{c}218 \\
0.9909\end{array}$ & $\begin{array}{c}158 \\
0.9958\end{array}$ & $\begin{array}{c}87 \\
0.998\end{array}$ & $\begin{array}{c}202 \\
0.9925\end{array}$ \\
\hline
\end{tabular}

Notes: The regressions include country and year fixed effects.

Standard errors in parentheses. * significant at 10\%; ${ }^{* *}$ significant at $5 \%$; ${ }^{* *}$ significant at $1 \%$

\section{The Square of GDP as an Additional Covariate}

Including the square of GDP as an additional covariate in the regression makes the partial effect of GDP on the commercial performance of movies a function of the GDP level. In a regression with country and year fixed effects, changes in GDP are an important predictor of changes in Internet and broadband penetration.

When using this alternative specification the estimation results are similar to those presented above except for the OLS estimates of the effect of file sharing on video rentals. Estimates for video rentals are shown in Table A3. This predicted file sharing impact is negative as in Table 6 , but smaller and with a very large standard error. ${ }^{30}$

\footnotetext{
${ }^{30}$ The regression results for the theatrical commercial performance and video sales are not presented, but are available on request.
} 
Table A3

OLS and Huber Robust Regressions on Video Rental Revenues (US\$ per capita)

\begin{tabular}{|c|c|c|c|c|}
\hline & \multicolumn{2}{|c|}{ Years 2000 Through 2002} & \multicolumn{2}{|c|}{ Years 2003 Through 2008} \\
\hline & OLS & $\begin{array}{c}\text { Huber Robust } \\
\text { II }\end{array}$ & OLS & $\begin{array}{c}\text { Huber Robust } \\
\text { IV }\end{array}$ \\
\hline \multirow[t]{2}{*}{ Internet Penetration } & $0.1552^{\star \star}$ & -0.0146 & -0.1211 & 0.0274 \\
\hline & $(0.0683)$ & $(0.0167)$ & $(0.0783)$ & $(0.0320)$ \\
\hline \multirow[t]{2}{*}{ Broadband Penetration } & 0.0497 & $0.3363^{\star \star *}$ & -0.0436 & -0.057 \\
\hline & $(0.1894)$ & $(0.0758)$ & $(0.1024)$ & $(0.0539)$ \\
\hline \multirow[t]{2}{*}{ GDP per capita } & $-2,913.9808^{*}$ & $1,584.8656^{\star * *}$ & $1,039.5756^{* * *}$ & $434.7294^{\star * *}$ \\
\hline & $(1657.5755)$ & $(448.7696)$ & $(315.9871)$ & $(159.2552)$ \\
\hline \multirow[t]{2}{*}{ GDP per capita (Square) } & $41,233.3320^{*}$ & $-21,421.4266^{\star \star \star}$ & $-9,332.8072^{* \star *}$ & $-6,053.8141^{\star * *}$ \\
\hline & $(23745.7250)$ & (6454.0529) & $(1813.3971)$ & $(936.7670)$ \\
\hline \multirow[t]{2}{*}{ Exchange Rate (in Logarithm) } & $-23.0892^{*}$ & 4.6275 & 5.391 & $13.0040^{\star * *}$ \\
\hline & (11.6409) & (3.4283) & $(7.1747)$ & (3.6969) \\
\hline \multirow[t]{2}{*}{ Price Index } & 0.2565 & -0.0384 & -0.0204 & $-0.1975^{* * *}$ \\
\hline & $(0.2102)$ & $(0.0603)$ & $(0.0769)$ & $(0.0502)$ \\
\hline \multirow[t]{2}{*}{ Population (in Millions) } & $-0.5340^{*}$ & $-0.3658^{* \star *}$ & $-0.5831^{* * *}$ & $-0.6874^{\star \star \star}$ \\
\hline & $(0.2822)$ & $(0.1027)$ & $(0.2079)$ & $(0.1058)$ \\
\hline Software Piracy & -7.7175 & 2.4105 & -16.6525 & $17.9857^{*}$ \\
\hline (Fraction of Lost Revenues) & (12.6032) & $(4.3409)$ & (17.5188) & $(9.7288)$ \\
\hline Observations & 54 & 53 & 104 & 104 \\
\hline R-Squared & 0.9897 & 0.999 & 0.9803 & 0.994 \\
\hline
\end{tabular}

Notes: The regressions include country and year fixed effects.

Robust standard errors in parentheses. * significant at 10\%; ${ }^{\star \star}$ significant at $5 \%$; ${ }^{\star \star \star}$ significant at $1 \%$

\section{Additional Robustness Checks}

Tables A4 through A8 present regressions analogous to those in Tables 4 through 8 but excluding the level of Internet penetration as a covariate. The tables show results qualitatively similar to those presented above.

Table A4

OLS Regressions on Theatrical Revenues (US\$ per capita)

\begin{tabular}{|c|c|c|c|c|}
\hline & $\begin{array}{l}\text { Years } 1996 \text { Through } \\
2002 \text { (broadband } \\
\text { assumed to be zero } \\
\text { when missing ) }\end{array}$ & $\begin{array}{l}\text { Years } 1998 \text { Through } \\
2002 \text { (broadband } \\
\text { assumed to be zero } \\
\text { when missing ) }\end{array}$ & $\begin{array}{c}\text { Years } 1998 \\
\text { Through } \\
2002\end{array}$ & $\begin{array}{c}\text { Years } 2003 \\
\text { Through } 2008\end{array}$ \\
\hline & $\mathbf{I}$ & II & III & IV \\
\hline \multirow[t]{2}{*}{ Broadband Penetration } & $0.2089^{* *}$ & $0.2060^{* *}$ & 0.1809 & 0.0033 \\
\hline & $(0.1054)$ & $(0.1029)$ & $(0.1331)$ & $(0.0519)$ \\
\hline \multirow[t]{2}{*}{ GDP per capita } & $376.1768^{* * *}$ & $431.2369^{* * *}$ & $581.7321^{\star * *}$ & $274.0390^{* * *}$ \\
\hline & $(74.8112)$ & $(84.0549)$ & $(145.4236)$ & $(55.2625)$ \\
\hline \multirow[t]{2}{*}{ Exchange Rate (in Logarithm) } & -0.7032 & 0.9528 & 2.6399 & $-4.8459^{\star}$ \\
\hline & $(0.7201)$ & $(1.1725)$ & (3.3321) & $(2.5227)$ \\
\hline \multirow[t]{2}{*}{ Price Index } & 0.0066 & -0.0076 & -0.0202 & $0.0143^{\star *}$ \\
\hline & $(0.0117)$ & $(0.0138)$ & $(0.0156)$ & $(0.0062)$ \\
\hline \multirow[t]{2}{*}{ Population (in Millions) } & $0.2063^{\star * *}$ & $0.2760^{\star * *}$ & $0.3595^{\star * *}$ & 0.0128 \\
\hline & $(0.0717)$ & $(0.0799)$ & $(0.0957)$ & $(0.0853)$ \\
\hline Software Piracy & 1.6315 & 1.1984 & 1.8668 & -3.2627 \\
\hline (Fraction of Lost Revenues) & $(2.4888)$ & $(3.0650)$ & (3.8567) & (6.1172) \\
\hline Observations & 211 & 154 & 89 & 191 \\
\hline R-Squared & 0.9755 & 0.9873 & 0.9949 & 0.9894 \\
\hline
\end{tabular}

Notes: The regressions include country and year fixed effects.

Robust standard errors in parentheses. ${ }^{*}$ significant at 10\%; ${ }^{* *}$ significant at $5 \%$; ${ }^{* *}$ significant at $1 \%$ 
Table A5

OLS Regressions on Theatrical Admission (Number of Tickets per capita)

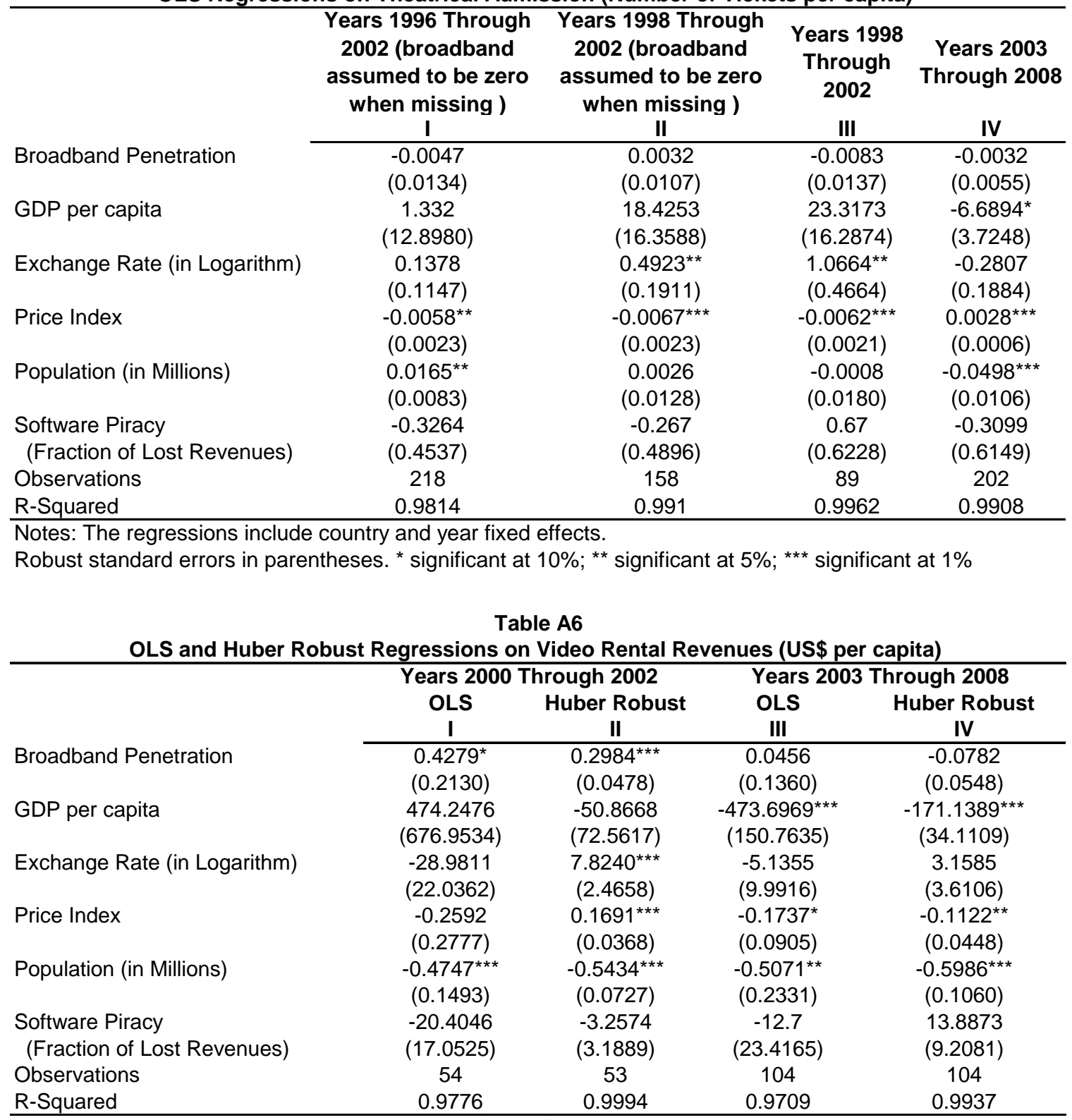

Notes: The regressions include country and year fixed effects.

Robust standard errors in parentheses. ${ }^{*}$ significant at 10\%; ${ }^{* *}$ significant at $5 \%$; ${ }^{* \star *}$ significant at $1 \%$ 
Table A7

OLS and Huber Robust Regressions on Video Sales Revenues (US\$ per capita)

\begin{tabular}{lcccc}
\hline & Years 2000 Through 2002 & \multicolumn{2}{c}{ Years 2003 Through 2008 } \\
& OLS & Huber Robust & OLS & $\begin{array}{c}\text { Huber Robust } \\
\text { IV }\end{array}$ \\
\cline { 2 - 5 } Broadband Penetration & I & II & III & -0.0717 \\
& $\left(0.1531^{* *}\right.$ & $1.6704^{\star * *}$ & -0.0794 & $(0.1589)$ \\
GDP per capita & $1,321.8825^{* *}$ & $986.0967^{\star * *}$ & $1,489.2363^{\star * *}$ & $1,251.2195^{\star * *}$ \\
& $(511.6433)$ & $(155.5236)$ & $(201.3043)$ & $(105.9441)$ \\
Exchange Rate (in Logarithm) & 0.67 & $-20.8685^{\star * *}$ & -7.6387 & -15.1645 \\
& $(22.5436)$ & $(5.3863)$ & $(14.6779)$ & $(11.0925)$ \\
Price Index & -0.4253 & -0.1242 & $0.4750^{* * *}$ & 0.1708 \\
& $(0.3965)$ & $(0.0811)$ & $(0.1719)$ & $(0.1356)$ \\
Population (in Millions) & $0.8207^{\star * *}$ & $0.9044^{\star * *}$ & -0.4397 & $-0.7271^{\star *}$ \\
& $(0.2684)$ & $(0.1659)$ & $(0.3877)$ & $(0.3196)$ \\
Software Piracy & 3.3273 & -2.4648 & -46.9357 & 4.6719 \\
(Fraction of Lost Revenues) & $(20.9232)$ & $(7.1506)$ & $(45.6944)$ & $(26.1696)$ \\
Observations & 54 & 54 & 108 & 108 \\
R-Squared & 0.9792 & 0.9983 & 0.9788 & 0.9881 \\
\hline
\end{tabular}

Notes: The regressions include country and year fixed effects.

Robust standard errors in parentheses. ${ }^{*}$ significant at 10\%; ${ }^{* *}$ significant at $5 \%$; ${ }^{* \star *}$ significant at $1 \%$

Table A8

OLS and Huber Robust Regressions on DVD Sales Revenues (US\$ per capita)

\begin{tabular}{|c|c|c|c|c|}
\hline & \multicolumn{2}{|c|}{ Years 2001 Through 2002} & \multicolumn{2}{|c|}{ Years 2003 Through 2008} \\
\hline & OLS & Huber Robust & $\begin{array}{l}\text { OLS } \\
\text { III }\end{array}$ & $\begin{array}{c}\text { Huber Robust } \\
\text { IV }\end{array}$ \\
\hline \multirow[t]{2}{*}{ Broadband Penetration } & 0.9246 & $1.3103^{\star * *}$ & 0.1656 & 0.2161 \\
\hline & $(0.5557)$ & $(0.1140)$ & $(0.2018)$ & $(0.1320)$ \\
\hline \multirow[t]{2}{*}{ GDP per capita } & $1,531.5446^{\star *}$ & $957.6536^{\star * *}$ & $1,492.5569^{* \star *}$ & $1,301.3519^{\star * *}$ \\
\hline & $(623.4348)$ & $(155.0396)$ & $(177.8384)$ & $(94.4801)$ \\
\hline \multirow[t]{2}{*}{ Exchange Rate (in Logarithm) } & 25.695 & 3.3823 & 15.1222 & 6.1112 \\
\hline & (25.9869) & $(4.9085)$ & $(9.6845)$ & $(5.9460)$ \\
\hline \multirow[t]{2}{*}{ Price Index } & -0.266 & $0.1145^{\star *}$ & 0.0328 & 0.0405 \\
\hline & $(0.3024)$ & $(0.0553)$ & $(0.0555)$ & $(0.0469)$ \\
\hline \multirow[t]{2}{*}{ Population (in Millions) } & $1.6494^{* * *}$ & $2.0760^{* * *}$ & -0.3341 & $-0.9510^{* * *}$ \\
\hline & $(0.3079)$ & $(0.1814)$ & $(0.3378)$ & $(0.2664)$ \\
\hline Software Piracy & 14.902 & 5.1531 & -20.5025 & 19.8937 \\
\hline (Fraction of Lost Revenues) & $(20.2112)$ & (7.1912) & $(28.4135)$ & (19.1903) \\
\hline Observations & 64 & 64 & 142 & 142 \\
\hline R-Squared & 0.9321 & 0.9939 & 0.972 & 0.987 \\
\hline
\end{tabular}

Notes: The regressions include country and year fixed effects.

Robust standard errors in parentheses. * significant at 10\%; ${ }^{* *}$ significant at $5 \%$; ${ }^{* \star *}$ significant at $1 \%$

Tables A9 through A13 present results excluding the exchange rate, inflation, software piracy, and population variables from the regressions.

Table A10 shows that the effect of file sharing on the number of admission tickets per capita is negative when excluding these covariates (although the standard errors are large). Using Columns I and IV (II and IV) indicates that file sharing reduced the number of tickets sold per capita in 2008 by $19 \%$ (23\%).

For video rentals, the broadband coefficients for the pre-file sharing and post-file sharing periods are similar in the OLS regressions from Columns I and III of Table A11. These estimates indicate that file sharing did not have an effect on video rentals (on their faces 
they actually imply that file sharing stimulates sales, although effect is small is size and the standard errors are very large). On the other hand, the Huber-robust estimates in Columns II and IV suggest that the file sharing effect on video rentals is negative.

Table A9

OLS Regressions on Theatrical Revenues (US\$ per capita)

\begin{tabular}{|c|c|c|c|c|}
\hline & $\begin{array}{l}\text { Years } 1996 \text { Through } \\
2002 \text { (broadband } \\
\text { assumed to be zero } \\
\text { when missing ) }\end{array}$ & $\begin{array}{l}\text { Years } 1998 \text { Through } \\
2002 \text { (broadband } \\
\text { assumed to be zero } \\
\text { when missing ) }\end{array}$ & $\begin{array}{c}\text { Years } 1998 \\
\text { Through } \\
2002\end{array}$ & $\begin{array}{c}\text { Years } 2003 \\
\text { Through } \\
2008\end{array}$ \\
\hline & $\mathbf{I}$ & II & III & IV \\
\hline Internet Penetration & $\begin{array}{l}-0.0069 \\
(0.0172)\end{array}$ & $\begin{array}{c}0.0075 \\
(0.0193)\end{array}$ & $\begin{array}{c}0.0103 \\
(0.0291)\end{array}$ & $\begin{array}{l}0.1100^{* * *} \\
(0.0364)\end{array}$ \\
\hline Broadband Penetration & $\begin{array}{l}0.2516^{* *} \\
(0.1064)\end{array}$ & $\begin{array}{l}0.1964^{* *} \\
(0.0909)\end{array}$ & $\begin{array}{c}0.1571 \\
(0.1309)\end{array}$ & $\begin{array}{l}-0.0418 \\
(0.0510)\end{array}$ \\
\hline GDP per capita & $\begin{array}{c}446.4680^{* * *} \\
(76.6672)\end{array}$ & $\begin{array}{c}529.3268^{* * *} \\
(100.9310)\end{array}$ & $\begin{array}{c}767.0908^{* * *} \\
(195.1590)\end{array}$ & $\begin{array}{c}324.8528^{\star * *} \\
(59.1272)\end{array}$ \\
\hline $\begin{array}{l}\text { Observations } \\
\text { R-Squared }\end{array}$ & $\begin{array}{c}233 \\
0.9828\end{array}$ & $\begin{array}{c}168 \\
0.9888\end{array}$ & $\begin{array}{c}94 \\
0.9918\end{array}$ & $\begin{array}{c}197 \\
0.9904\end{array}$ \\
\hline \multicolumn{5}{|c|}{$\begin{array}{l}\text { Notes: The regressions include country and year fixed effects. } \\
\text { Robust standard errors in parentheses. }{ }^{*} \text { significant at } 10 \% ;{ }^{* *} \text { significant at } 5 \% ;{ }^{* *} \text { significant at } 1 \%\end{array}$} \\
\hline & $\begin{array}{l}\text { Years } 1996 \text { Through } \\
2002 \text { (broadband } \\
\text { assumed to be zero } \\
\text { when missing ) }\end{array}$ & $\begin{array}{l}\text { Years } 1998 \text { Through } \\
2002 \text { (broadband } \\
\text { assumed to be zero } \\
\text { when missing ) }\end{array}$ & $\begin{array}{c}\text { Years } 1998 \\
\text { Through } \\
2002\end{array}$ & $\begin{array}{c}\text { Years } 2003 \\
\text { Through } \\
2008\end{array}$ \\
\hline & $\mathbf{I}$ & II & III & IV \\
\hline Internet Penetration & $\begin{array}{l}0.0044^{*} \\
(0.0025)\end{array}$ & $\begin{array}{c}0.0019 \\
(0.0027)\end{array}$ & $\begin{array}{c}0.0016 \\
(0.0037)\end{array}$ & $\begin{array}{l}0.0098^{* * *} \\
(0.0030)\end{array}$ \\
\hline Broadband Penetration & $\begin{array}{c}0.0102 \\
(0.0127)\end{array}$ & $\begin{array}{c}0.0153 \\
(0.0097)\end{array}$ & $\begin{array}{l}0.0065 \\
(0.0157)\end{array}$ & $\begin{array}{l}-0.0114^{\star *} \\
(0.0049)\end{array}$ \\
\hline GDP per capita & $\begin{array}{c}9.4973 \\
(12.5503)\end{array}$ & $\begin{array}{c}17.3121 \\
(16.1497)\end{array}$ & $\begin{array}{c}3.4687 \\
(13.3958)\end{array}$ & $\begin{array}{l}-5.1576^{\star} \\
(2.9874)\end{array}$ \\
\hline Observations & 246 & 176 & 94 & 211 \\
\hline R-Squared & 0.9853 & 0.9923 & 0.9957 & 0.9899 \\
\hline
\end{tabular}

Notes: The regressions include country and year fixed effects.

Robust standard errors in parentheses. * significant at 10\%; ${ }^{* *}$ significant at $5 \%$; ${ }^{* *}$ significant at $1 \%$ 
Table A11

OLS and Huber Robust Regressions on Video Rental Revenues (US\$ per capita)

\begin{tabular}{lcccc}
\hline & \multicolumn{2}{c}{ Years 2000 Through 2002 } & \multicolumn{2}{c}{ Years 2003 Through 2008 } \\
& OLS & Huber Robust & OLS & $\begin{array}{c}\text { Huber Robust } \\
\text { IV }\end{array}$ \\
\cline { 2 - 5 } Internet Penetration & I & II & III & -0.0043 \\
& $\left(0.2141^{* *}\right.$ & -0.0109 & -0.0288 & $(0.0307)$ \\
Broadband Penetration & $0.0839)$ & $(0.0145)$ & $(0.0886)$ & -0.0671 \\
& $(0.1761)$ & $0.1802^{* * *}$ & 0.1132 & $(0.0564)$ \\
GDP per capita & 384.247 & $(0.0540)$ & $(0.1269)$ & -30.6385 \\
Observations & $(427.7400)$ & $(82.2150)$ & $(168.5535)$ & $(39.1609)$ \\
R-Squared & 54 & 53 & 104 & 104 \\
\hline Notes: The & 0.984 & 0.9991 & 0.9636 & 0.9904 \\
\hline
\end{tabular}

Notes: The regressions include country and year fixed effects.

Robust standard errors in parentheses. ${ }^{*}$ significant at $10 \% ;{ }^{* *}$ significant at $5 \% ;{ }^{* * *}$ significant at $1 \%$

Table A12

OLS and Huber Robust Regressions on Video Sales Revenues (US\$ per capita)

\begin{tabular}{|c|c|c|c|c|}
\hline & \multicolumn{2}{|c|}{ Years 2000 Through 2002} & \multicolumn{2}{|c|}{ Years 2003 Through 2008} \\
\hline & OLS & $\begin{array}{c}\text { Huber Robust } \\
\text { II }\end{array}$ & $\begin{array}{l}\text { OLS } \\
\text { III }\end{array}$ & $\begin{array}{c}\text { Huber Robust } \\
\text { IV }\end{array}$ \\
\hline \multirow[t]{2}{*}{ Internet Penetration } & 0.117 & $0.0758^{\star \star *}$ & 0.2271 & -0.0764 \\
\hline & $(0.0984)$ & $(0.0202)$ & $(0.1611)$ & $(0.0909)$ \\
\hline \multirow[t]{2}{*}{ Broadband Penetration } & $1.1764^{* * *}$ & $1.4886^{* * *}$ & -0.1917 & -0.1351 \\
\hline & $(0.3786)$ & $(0.1005)$ & $(0.2251)$ & $(0.1619)$ \\
\hline \multirow[t]{2}{*}{ GDP per capita } & $920.4999^{*}$ & $799.9797^{\star \star \star}$ & $1,523 \cdot 3919^{* * *}$ & $1,210.7196^{\star \star *}$ \\
\hline & $(476.4969)$ & $(146.1358)$ & $(216.2190)$ & $(117.1564)$ \\
\hline Observations & 54 & 54 & 108 & 108 \\
\hline R-Squared & 0.9772 & 0.9979 & 0.9771 & 0.9849 \\
\hline
\end{tabular}

Notes: The regressions include country and year fixed effects.

Robust standard errors in parentheses. ${ }^{*}$ significant at $10 \% ;{ }^{* *}$ significant at $5 \%$; ${ }^{* *}$ significant at $1 \%$

Table A13

OLS and Huber Robust Regressions on DVD Sales Revenues (US\$ per capita)

\begin{tabular}{lcccc}
\hline & \multicolumn{2}{c}{$\begin{array}{c}\text { Years 2001 Through 2002 } \\
\text { OLS }\end{array}$} & Huber Robust & \multicolumn{2}{c}{ Years 2003 Through 2008 } \\
OLS & Huber Robust \\
IV
\end{tabular}

Notes: The regressions include country and year fixed effects.

Robust standard errors in parentheses. ${ }^{*}$ significant at $10 \% ;{ }^{* *}$ significant at $5 \% ;{ }^{* * *}$ significant at $1 \%$ 